\title{
FRANKLIN BOULEVARD REDEVELOPMENT PROJECT AREA MARKET ANALYSIS
}

\author{
A Project \\ presented to \\ the Faculty of California Polytechnic State University, \\ San Luis Obispo
}

\author{
In Partial Fulfillment \\ of the Requirements for the Degree \\ Master of City and Regional Planning
}

by

Joshua R. Chapman

December 2010 
Franklin Boulevard Market Analysis

(C) 2010

Joshua R. Chapman

ALL RIGHTS RESERVED 
COMMITTEE MEMBERSHIP

TITLE:

AUTHOR:

DATE SUBMITTED:

COMMITTEE CHAIR: $\quad$ Kelly Main, Assistant Professor

COMMITTEE MEMBER: Lisa A. Wise, Lecturer

COMMITTEE MEMBER: Desmond Parrington, Infill Coordinator, City of Sacramento 


\begin{abstract}
Franklin Boulevard Redevelopment Project Area Market Analysis

Joshua R. Chapman
\end{abstract}

The following Market Analysis is an analysis of the Franklin Boulevard Redevelopment Project Area. The analysis is divided into the following four sections:

- Planning Context

- Real Estate Market Conditions

- Emerging Market Opportunities \& Case Studies

- Conclusion

The report serves as an opportunity to aide stakeholders of the Franklin Boulevard Redevelopment Project Area (Project Area). Stakeholders include residents, business owners, the City of Sacramento, County of Sacramento, Sacramento Housing and Redevelopment Agency (SHRA), and the North Franklin District Business Association (NFDBA). The stakeholders are continually searching for data and creative examples of how to transform the area into a premier "urban" destination in the Sacramento Region.

Keywords: Franklin Boulevard, market analysis, economic development 


\section{Table of Contents}

1 Project Introduction 1

Executive Summary . . . . . . . . . . . . . . 1

Introduction . . . . . . . . . . . . . . . 4

2 Planning Context 7

Potential Avenues for Government Incentives . . . . .11

3 Real Estate Market Conditions 13

Demographic Projections . . . . . . . . . . . . 14

Demographic Diversity . . . . . . . . . . . .16

Commercial Market . . . . . . . . . . . . . . . 17

$4 \quad$ Emerging Market Opportunities \& Case Studies 21

Case Studies . . . . . . . . . . . . . . . . . . . 24

Lessons Learned. . . . . . . . . . . . . . . 30

Challenges . . . . . . . . . . . . . . . . 31

5 Conclusion 33

Recommendations . . . . . . . . . . . . . . .33

Bibliography . . . . . . . . . . . . 36

6 Appendices 


\section{Figures}

1 Project Introduction 1

2 Project Planning Context $\quad 7$

Figure 2.1: SHRA Project Area Map . . . . . . . . . . 9

3 Real Estate Market Conditions 13

Figure 3.1: Total Households, 1990 - 2012 . . . . . 14

Figure 3.2: Households by Size, 2007 . . . . . . . 14

Figure 3.3: Age Distribution, 2007 . . . . . . . . 14

Figure 3.4: Total Population Projections, 1990 - 2012 . 15

Figure 3.5: Households by Income, 2007 . . . . . . 15

Figure 3.6: Age Distribution Projections, 2012 . . 16

Figure 3.7: Households by Size Projections, 2012 . 16

Figure 3.8: Housing Tenure, $2000 \& 2007$. . . . . 16

Figure 3.9: Pop. Projections by Race/Ethnicity . . . 17

Figure 3.10: S. County Pop. Projections, 2000 - 2030 . 17

Figure 3.11: Retail Sales Volume, 2007 . . . . . . . 19 


\section{Figures Cont'd}

$4 \quad$ Emerging Market Opportunities \& Case Studies $\quad 21$

5 Conclusion

6 Appendices

Figure 6.1: Population Pyramid, 2007 - 1 Mile. . . . 39

Figure 6.2: Population Pyramid, 2007 - 2 Mile . . . 39

Figure 6.3: Population Pyramid, 2007 - 3 Mile . . .40

Figure 6.4: Population Pyramid, 2012 - 1 Mile . . . . 40

Figure 6.5: Population Pyramid, 2012 - 2 Mile . . . . .41

Figure 6.6: Population Pyramid, 2012 - 3 Mile . . .41

Figure 6.7: Households by Income, 2007 . . . . .42

Figure 6.8: Households by Size. 2007 . . . . . . .42

Figure 6.9: Households by Size, 2012 . . . . . . .43

Figure 6.10: Total Households . . . . . . . . . . .43

Figure 6.11: Households by Income, 2012． . .44

Figure 6.12: CBRE Market View, Sacramento . . . .45 
viii Franklin Boulevard Market Analysis

Page Intentionally Left Blank 


\section{Executive Summary}

The following Market Analysis is an analysis of the Franklin Boulevard Redevelopment Project Area. The analysis is divided into the following four sections:

- Planning Context

- Real Estate Market Conditions

- Emerging Market Opportunities \& Case Studies

- Conclusion

Combined, the four sections highlight the potential the Project Area has for becoming a "urban" destination for residents of the Sacramento Community to experience. A common thread weaved into the document touches upon the efforts made by the local business community to continually search for ways to improve the economic status of the Project Area. Through the North Franklin District Business Association (NFDBA), businesses have been able to forge relationships with the City and County in order to secure funds and ultimately improve the economic and social climate of the area. The case studies located at the end of the analysis contain examples of traditionally underserved ethnic communities overcoming myriad barriers in order to create developments which garner profits for businesses while serving as community gathering places. The case studies highlight potential avenues for success for the Project Area relying upon community input, private/public partnerships, and creative financing.

\section{Planning Context:}

DISTRICT
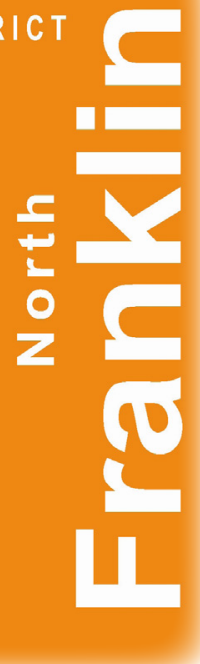

The Franklin Boulevard Project Area is a diverse community which has served as a commercial corridor for decades. Unfortunately, over the years, Franklin Boulevard has been suceptible to the same issues faced by many adjacent communities. Issues have ranged from acts of violent crime, to vandalism, to a lack of funds to provide adequate levels of infrastructure.

Fortunately, the Project Area has begun to turn the page on past incidences which have plagued the area for sometime. Spurred on by a group of community leaders from the public and private sectors, Franklin Boulevard has begun to be reborn. Public and private stakeholders have pooled resources together to improve the Project Area in multiple facets and finally overcome the negative public perception that has plagued the area in the past. 


\section{Real Estate Market Conditions:}

The following section contains demographic attributes for the Project Area at a 1, 2, \& 3 mile radius with the overarching goal of obtaining a greater understanding of the demographic composition of the area. In addition to current data, demographic projections for 2012 are provided.

The analysis depicts an area which possesses a diverse community which has the potential to become a "urban" destination for the Sacramento region. However, real estate industry reports show that the Project Area is suffering similar issues that most areas are dealing with due to the overall state of the economy in the United States.

\section{Emerging Market Opportunities \& Case Studies:}

Diverse ethnic populations have and will continue to emerge as an ever increasing segment of our society. Businesses have and will continue to target ethnic clientele to stay competitive in the marketplace. Businesses need to continually be cognizant of emerging market opportunities to retain a competitive edge, especially during tough economic times. The Project Area's diverse community is hoping to be able to capitalize on the ever increasing

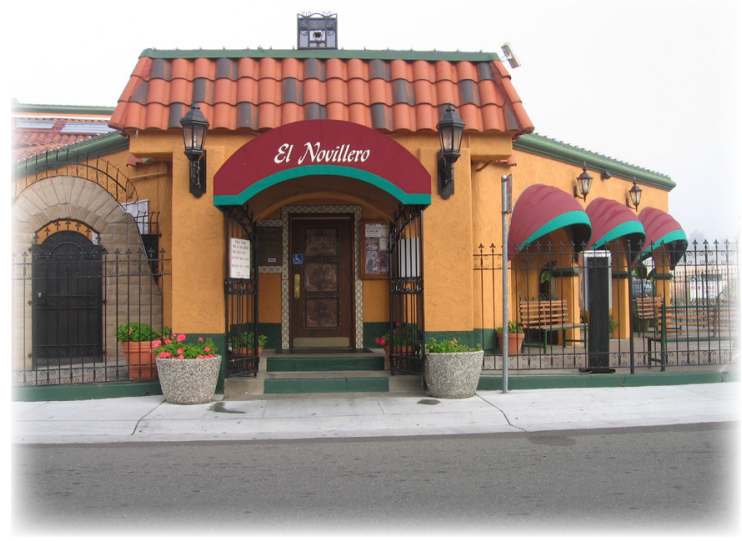

desire of retailers to find new avenues to reach ethnic consumers.

The case studies provided in the end of this section illustrate that businesses can become more than an instrument for financial profit. Businesses working together with government and community leaders can transform traditionally underserved communities physically, fiscally, and help create or enhance an existing community gathering place.

\section{Conclusion:}

The conclusion builds upon the previous chapters to propose recommendations that Project Area stakeholders can build upon to transform the area into an "urban" destination which celebrates the history and diversity of Franklin Boulevard.

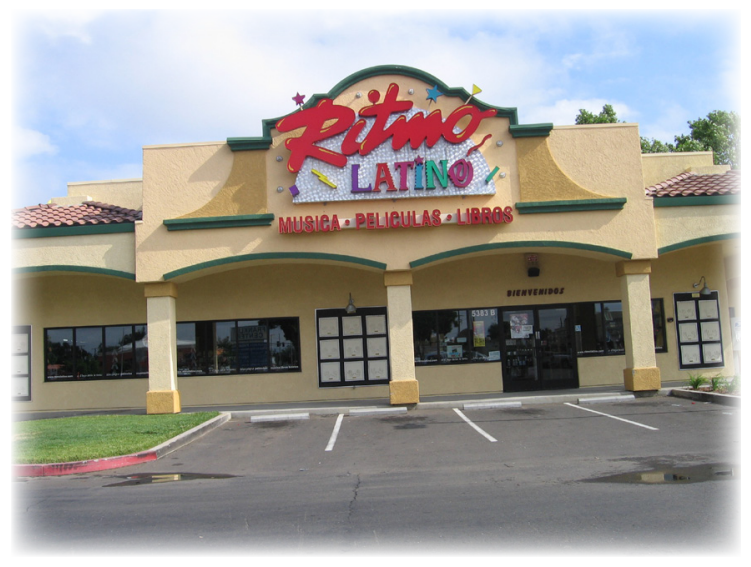


Page Intentionally Left Blank 


\section{Introduction}

The following report serves as an opportunity to aide stakeholders of the Franklin Boulevard Redevelopment Project Area (Project Area). Stakeholders include residents, business owners, the City of Sacramento, County of Sacramento, Sacramento Housing and Redevelopment Agency (SHRA), and the North Franklin District Business Association (NFDBA). The stakeholders are continually searching for data and creative examples of how to transform the area into a premier "urban" destination in the Sacramento Region. The information provided in the report should play a role in the desired transformation.

The research activities, site visits, collection of most recent available data and trend indicators, and other tasks commenced in April 2009. Meetings with Franklin Boulevard area stakeholders primarily occurred during August 2008.

Data sources, including indicators available through April 2009, have been utilized wherever possible. Such information is always footnoted and sourced so that the reader will understand the time dating of the data sets as well as the opportunity to review sources to garner a greater understanding of the material.

In the assessment of opportunities and demand in the Project Area, the consultant was directed to focus on the Franklin Boulevard corridor, which may host most of the potential upcoming new redevelopment activity. The length is 2.95 miles, with 1.65 miles being in the City and 1.3 miles (south end) being in the County ${ }^{1}$. Although the redevelopment project area was adopted in 1994, the City and County had been working on economic development challenges in the area since $1982^{2}$.

The primary goal of the project is to identify potential market opportunities and to make corresponding recommendations for the Project Area to enhance its ability to become a premier "urban" center in the Sacramento Region. In order to achieve the aforementioned goal; a two-pronged approach has been chosen. 
The approach seeks to do the following:

- Identify the current financial climate of the Project Area

- Identify potential market opportunities for fiscal success

The end of the report contains a series of recommendations which rely upon an accurrate assessment of the financial climate of the Project Area and examples of potential market opportunities. The recommendations serve as a resource for Project Area stakeholders to reference as they pursue potential avenues in order to evolve into an area where many more Sacramento residents come together to shop and eat.

To achieve the first objective of the selected approach, the first two sections review the history of the Project Area and highlight current and projected demographic data coupled with information regarding current market rates and vacancies for commercial, industrial, and retail space.
The third section is dedicated to offering potential avenues in which the Project Area can take advantage of it's existing diversity to position itself as a community shopping and gathering place for a variety of people. The third section also reviews opportunities and constraints present in the Project Area. Case studies are used to review potential ways to aide stakeholders in transforming the area into the premier "urban" destination in the Sacramento Region.

The fourth section is centered around the findings culled from the previous three sections. A series of recommendations for stakeholders are based on the findings. The overarching goal of the report is to utilize the findings and subsequent recommendations to be an instrument for change in the Project Area.

\section{"We cannot direct the wind, but we can adjust the sails."}

-- Anonymous

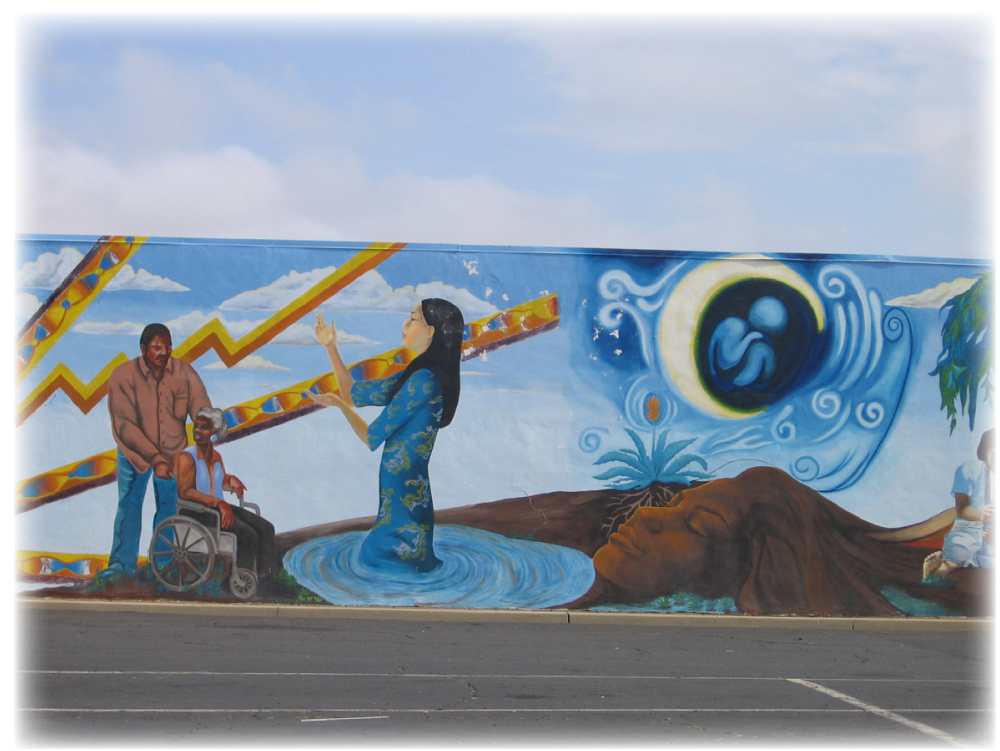


6 Franklin Boulevard Market Analysis

Page Intentionally Left Blank 


\section{Planning Context}

The Franklin Boulevard Project Area is a diverse community which has served as a commercial corridor for decades. Historical records indicate that Franklin Boulevard's use as a commercial corridor hearkens back to the days when wagons were the primary mode of transportation ${ }^{3}$.

As time marched on, the construction of railroad tracks and Highway 99 began to physically define and separate the area from adjacent communities (please see the adjacent text box to get a greater understanding of the history of the North Franklin Distric Business Association (NFDBA)).

\section{North Franklin District Business Association HISTORY}

In 1985, a group of concerned business owners created The Franklin Boulevard Business Association. Originally, the district represented by the Association was comprised of the area on Franklin Boulevard from Sutterville Road to Fruitridge Road. The Sacramento City Council and County Board of Supervisors established the Franklin boulevard Redevelopment Area on December 14th, 1994. The redevelopment area contains approximately 1,440 acres, which makes it one of the largest in Sacramento County. The redevelopment area extends from Suterville Road on the north, Highway 99 on the east, Turnbridge on the south, and 24th Street and the Union Pacific Railroad right-of-way on the west. An additional section on Franklin Boulevard north from Sutterville Road to Broadway is also included within the Association's boundaries.

A Business Improvement Area (BIA) was formed in 1986. An assessment paid by each business within the established boundaries of the BIA is used to fund programs of mutual benefit. In August 2004, the City Council and County Board of Supervisors, along with property owners approved a three-year term for a Property and Business Improvement District (P-BID) starting on Franklin at Wilmington Avenue south to 33rd Avenue. Renewal and expansion of the P-BID for a five-year term was passed by the property owners and the City and County of Sacramento in July 2007. The boundaries are Franklin Boulevard starting at Sutterville Road and continuing south to 47 th Avenue.

Source: North Franklin District Strategic Plan (2008), High Points Consulting 2008 
Eventually, the City of Sacramento annexed a significant portion of the Project Area, dividing into County and City jurisdictions (please see the adjacent page for a map highlighting the Franklin Redevelopment Area as defined by the Sacramento Housing and Redevelopment Agency (SHRA)).

Through time, Franklin Boulevard has been suceptible to issues faced by many adjacent communities (please see the adjacent column for a brief review of Franklin Boulevard's history). Issues have ranged from acts of violent crime, to vandalism, to a lack of funds to provide adequate levels of infrastructure.

Fortunately, a process of amelioration has been going on for some time. Spurred on by a group of community leaders from the public and private sectors, Franklin Boulevard has begun to be reborn. The synergy created from various stakeholders has engendered a sense of community among them. To this end,

\section{Early History}

Franklin Boulevard's history as a commercial corridor goes back to its early use as an old wagon trail that connected Sacramento to the town of Franklin to the south. Pre-19th century maps list the boulevard as Lower Stockton Road.

Most of the area within the project limits existed outside of the Sacramento city limits until roughly 1953 when the City annexed portions of Franklin Boulevard south of 18th Avenue. Today, the project area is divided between City and County jurisdictions.

\section{Land Use and Infrastructure}

Historical zoning and Sanborn maps dating back to the early 1950's show the Boulevard's characteristic mix of commercial, light industrial, and residential land uses. One significant change in the zoning maps between 1954 and 1964 was the rezoning of singlefamily residential zones in the area now called East Side of North City Farms (ESNCF) to mixed commercial/residential. During this period, starting in 1954, land was being acquired just to the east of Franklin Boulevard for the construction of SR 99 (Highway 99). SR 99 was completed in 1961 and had the profound effect of cutting through the existing urban grid to leave behind fragments of what were once cohesive neighborhoods.

The construction of SR 99 also had a significant effect on the vitality of Franklin Boulevard as a commercial corridor. Historically, Franklin Boulevard served as a major thoroughfare from Sacramento to regions south. Businesses along the corridor benefited from the traffic flow. SR 99 had the effect of diverting a significant amount of the north/south traffic from Franklin Boulevard, which impacted the vitality of the commercial corridor. 


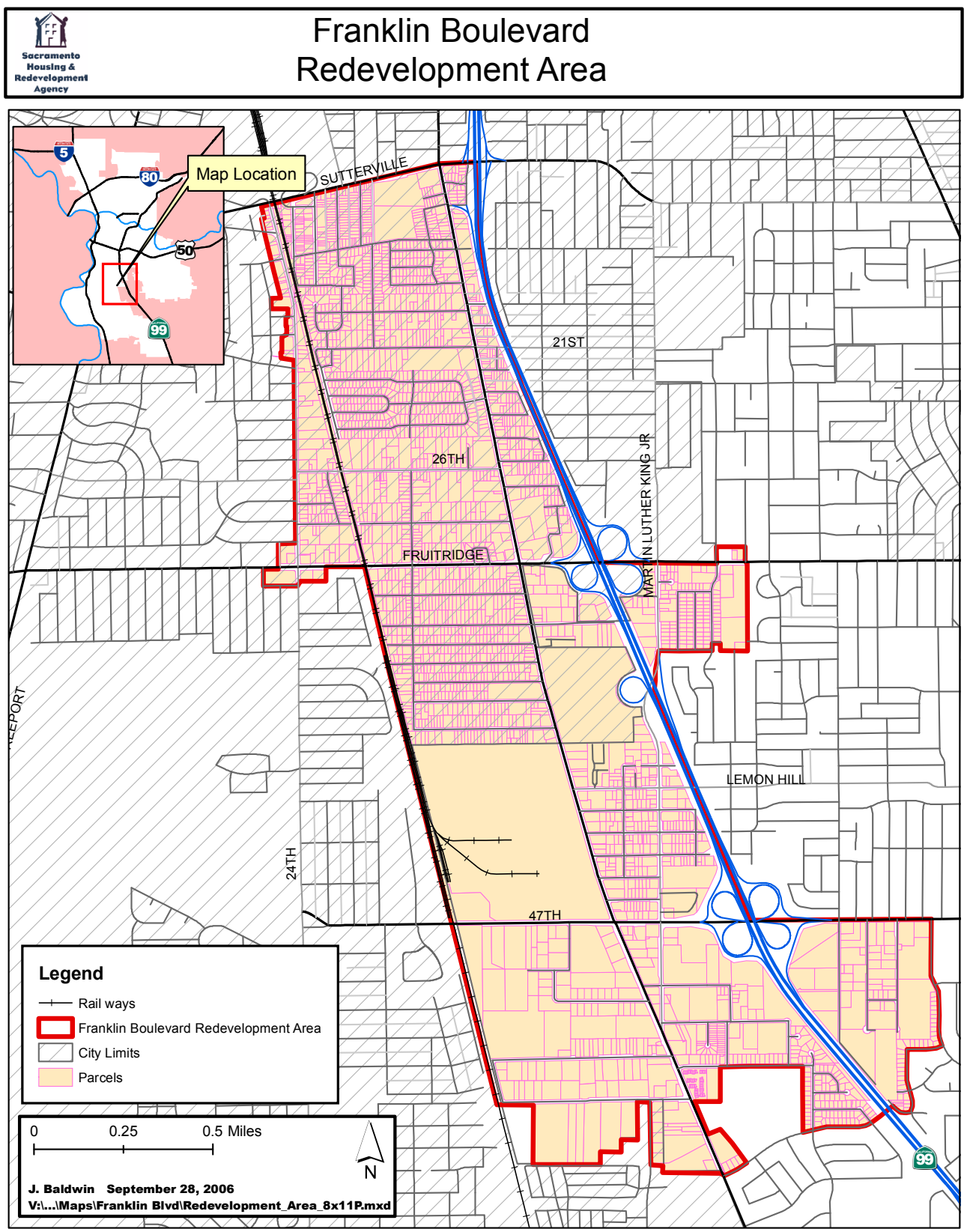

Figure 2.1 
public and private stakeholders have pooled resources together to improve the Project Area in myriad facets and finally overcome the negative public perception that has plagued the area in the past.

The text boxes below contain the mission statement and the guiding principles, which the NFDBA utilizes as its foundation for making key decisions ${ }^{4}$.
The guiding principles place emphasis on the value of diversity and the importance of community. While profit is essential to business success, the NFDBA recognizes that the overall health and well being of the community as a whole requires a solid relationship between residents and businesses based on trust and mutual respect for one another.

\section{NFDBA MISSION STATEMENT}

The North Franklin District Business Association's Mission is to create a climate in which business and property owners can be successful by promoting economic development and quality of life throughout the North Franklin District.

\section{NFDBA GUIDING PRINCIPLES}

- We place a high value on people from our dedicated leadership to the strong individual commitments of our members to the many exceptional partners we have and will continue to have as we move forward.

- We believe there is strength in diversity. We strive to be inclusive, to be respectful of differences, and we are open to sharing our knowledge and experience and learning without judgment.

- We honor a strong work ethic. We will work hard and remain accountable to each other as we serve as a springboard to North Franklin District's renewal and expansion. We will keep our commitments, broaden our possibilities, and reach for solutions where everybody wins.

- We recognize the importance of community. We seek to make connections and build trusting relationships based on open communication, respect and a contagious passion for our work and for the prosperous future of the North Franklin District, its businesses and residents.

Source: North Franklin District Strategic Plan (2008), High Points Consulting 2008 


\section{Potential Avenues for Government Incentives:}

The County of Sacramento, City of Sacramento, and the Sacramento Housing and Redevelopment Agency (SHRA) provide substantial staff resources to spur on infill development within the Project Area and within adjacent areas. Staff participation ranges from coordinating with other agencies to aiding developers during the entitlement and permitting processes.

Existing and potential funding sources inlude:

- Community Development Block Grants (CDBG)

- Property and Business Improvement District (P-BID)

- Safe Routes to School Program

- Propositions 1B \& 1C Funds

- Federal Transit Administration's Livable Communities Initiative

"What we have before us are some breathtaking opportunities disguised as insoluble problems."

-- John W. Gardner

\section{Franklin Boulevard -- Impetus for} Redevelopment District

In the mid-1980s, the Sacramento Union newspaper named Franklin Boulevard the ugliest street in Sacramento.

Sacramento's late Mayor Joe Serna was a city councilman at the time, and was so upset by the published slam against a major street within his council district that he pushed for and won approval of the first Franklin Boulevard redevlopment district.

Source: Sacramento Business Journal - July, 24, 2006 - by Michael Pulley. Data accessed @ http://sacramento.bizjournals.com/sacramento/stories/2006/07/24/focus1.html

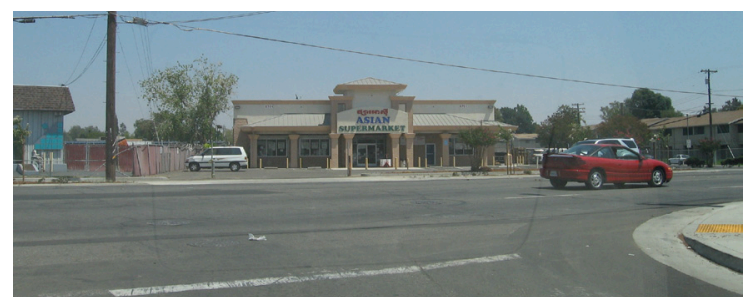


12 Franklin Boulevard Market Analysis

Page Intentionally Left Blank 


\section{Real Estate Market Conditions}

The following chapter provides an overview of the Project Area's real estate market conditions. The section relies on data garnered from private and public entities including MapInfo Incorporated, LoopNet Incorporated, The California Department of Finance (DoF), U.S. Census Bureau (2000 U.S. Census), CB Richard Ellis (CBRE), and knowledgeable local informants.

Wherever possible, the consultant (JRC) utilized data sets, which covered identical physical parameters (census tracks, zip codes, radii, etc...) to give the reader a clear and accurate depiction of the Project Area's real estate market. However, due to a finite amount of fiscal resources and time, coupled with the lack of overall data created specifically for the Project Area, JRC blended data, which covers varying physical parameters in able to analyze the Project Area's real estate market. The context and actual physical parameters of all data presented are clearly and accurately defined and identified. In addition to providing detailed demographic data, the section promotes a clear understanding of the data through the use of graphs and tables.

For a substantial portion of the demographic attributes, the consultant analyzed the Project Area at a $1,2, \& 3$ mile radius. The radii originated from a specifically targeted address (5383 Franklin Boulevard) to ensure uniformity of data with the overarching goal of obtaining a greater understanding of the demographic composition in the area. The selected location was chosen because of its proximity towards the center of the redevelopment project area and for being the current location of the North Franklin District Business Association (NFDBA).

The following indicators were utilized:

- Total Population

- Population by Age

- Population by Race/Ethnicity

- Households by Size

- Households by Tenure

- Housing Units by Type -- Owner/Renter

- Households by Income Distribution

The majority of the indicators are supplemented with projections for 2012. Please refer to the Appendices for additional data.

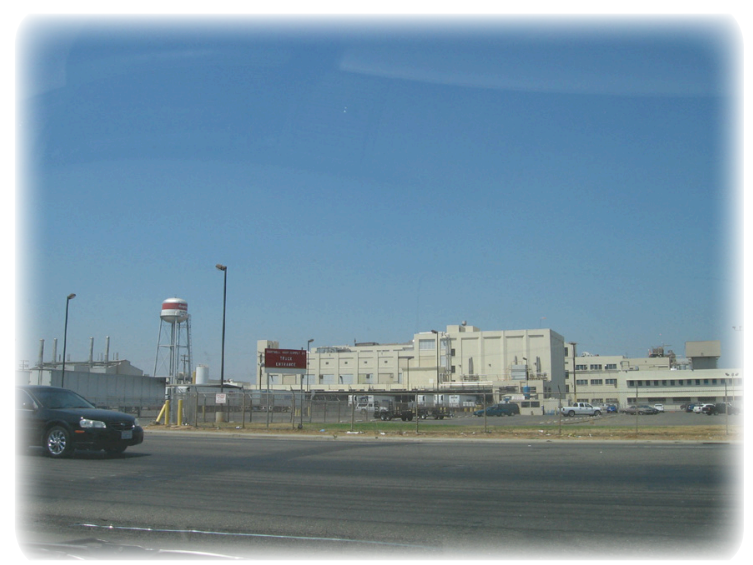




\section{Demographic Conditions (Current \& Projected):}

The following section relies on data from the U.S. Census $(1990,2000)$ and MapInfo Incorporated. Many of the figures presented in this section primarily focus on 2007 and/or 2012 projections in 1, 2, \& 3 mile radii originating from 5383 Franklin Boulevard.

Possessing over 169,000 residents (Figure 3.4) within a 3 mile radius and over 67,000 households (Figure 3.1), the Project Area represents a significant community within Sacramento 5 .

Figure 3.2 illustrates the population density within the Project Area. The average household size is 2.5 persons per household within a 3 mile radius and up to 3.0 persons per household within a 1 mile radius. The Project Area possesses approximately 25,246 households which contain a minimum of 3.0 persons per household.

The level of density is of great value to current and future businesses. The increased levels of density allows businesses to position themselves within a market area which grants them increased access to a larger clientele base than less populated areas.

In additon to being densely populated, the Project Area posseses a significant level of people under the age of 18 . As indicated in Figure 3.3, approximately 25 percent of the Project Area is composed of persons under 18 years of age $e^{6}$.

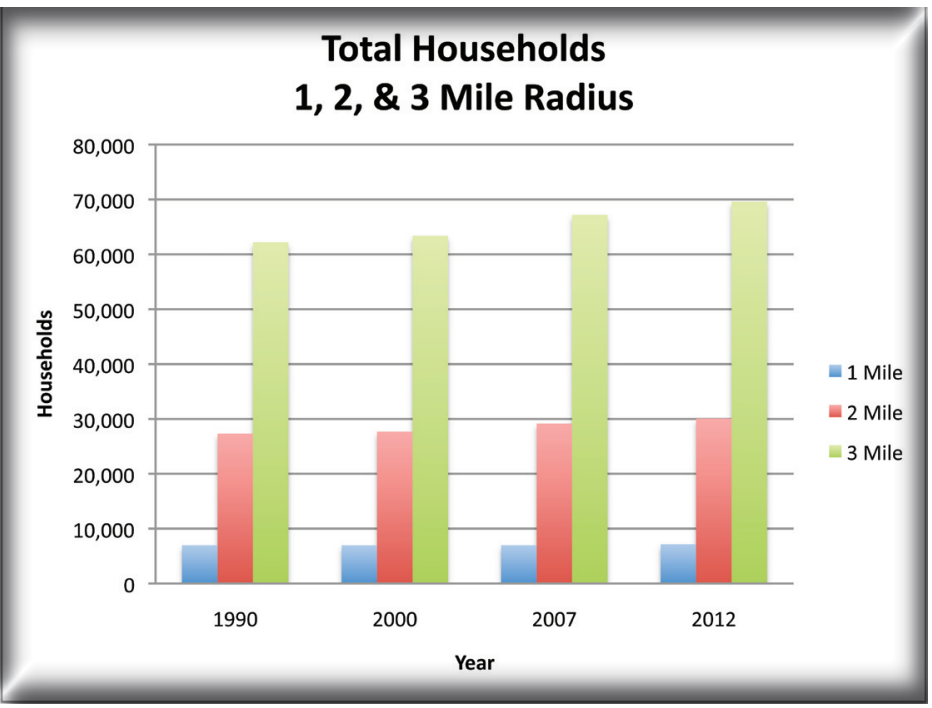

Figure 3.1

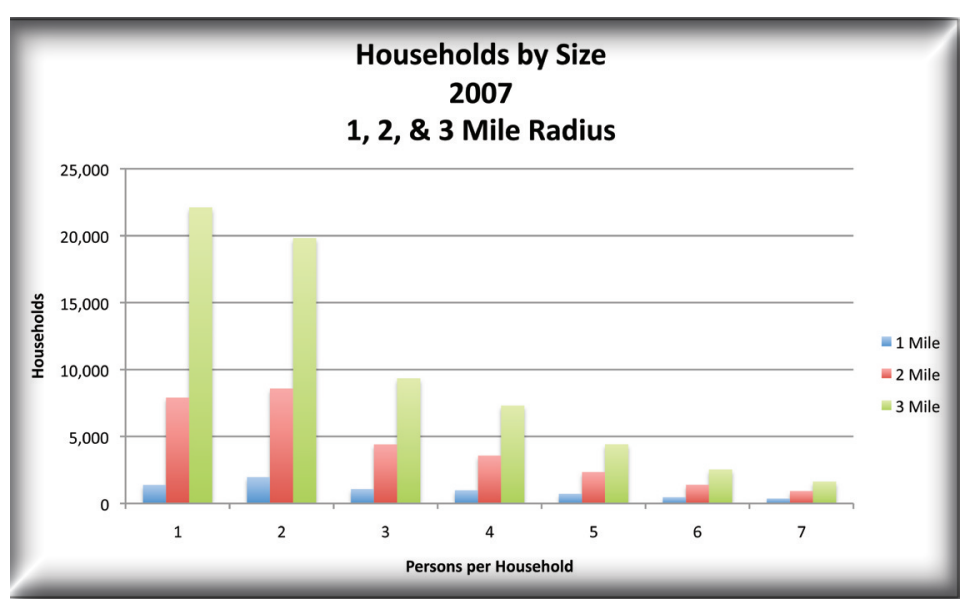

Figure 3.2

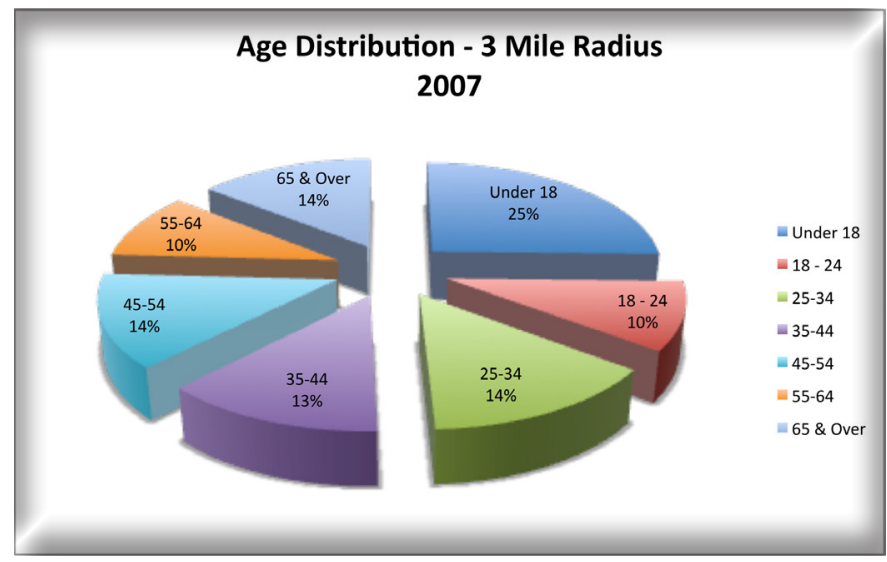




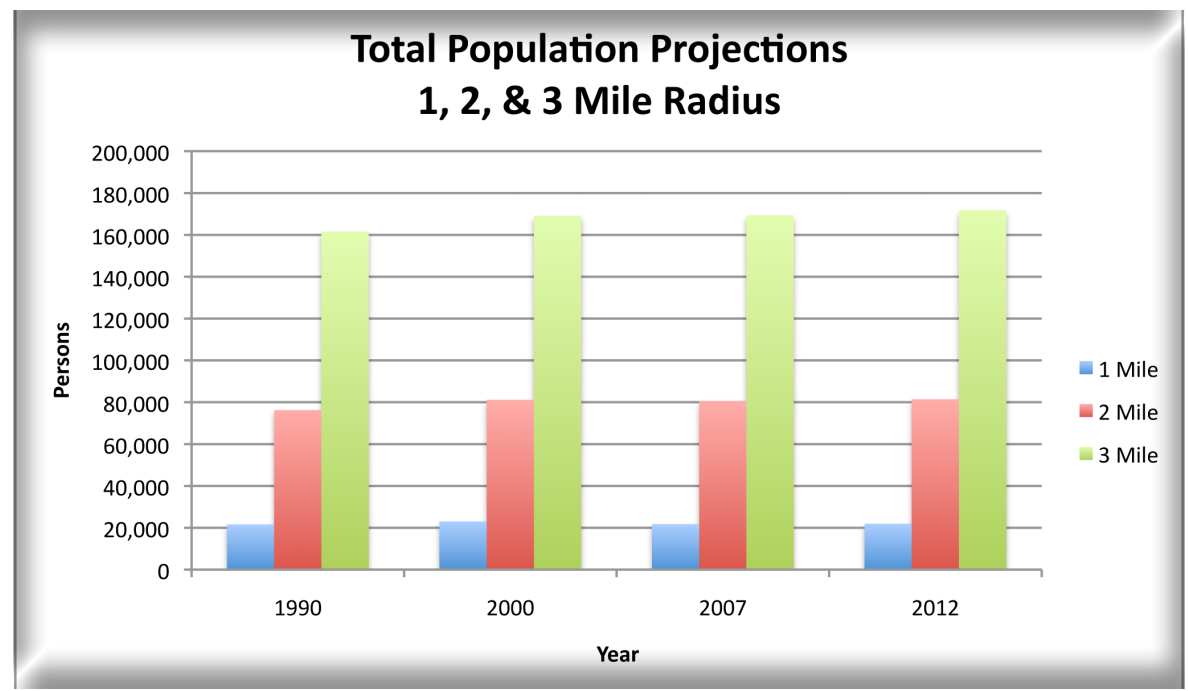

Figure 3.4

Households by Income Distribution

2007

1, 2, \& 3 Mile Radius

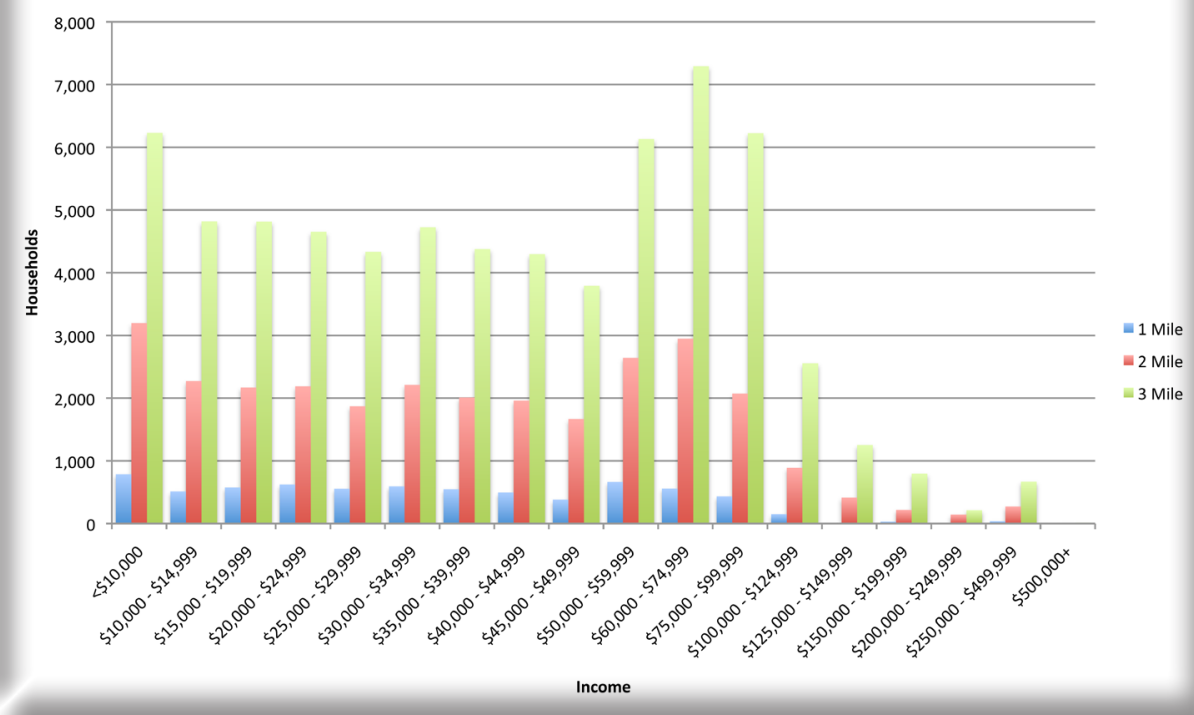

Figure 3.5 
The Project Area's household size, housing tenure, and income levels impact the market in several ways. For example, though the area may have a lower per capita income than suburban counterparts, the increased population density means that households may collectively possess greater buying power than some suburban areas which have a lower density population.

\section{Demographic Diversity:}

One of the Project Area's greatest assets is the presence of a robust and diverse population. Within a 1 mile radius, figure 3.9 shows that in 2000 , 5,698 Hispanics (29 percent of total population) and 5,023 Asians (25 percent of total population) lived in the Project Area. The percentage of Hispanics and Asians combine to make up more than half of the total population (54 percent) in the Project Area. Figure 3.10 shows that at the County level, Hispanics and Asians combine to make a little over a quarter (26 percent) of the County's population in 2000 . The businesses and residents located in the Project Area and its periphery are fortunate to be able to benefit from such diversity. The 2012 projections for the Project

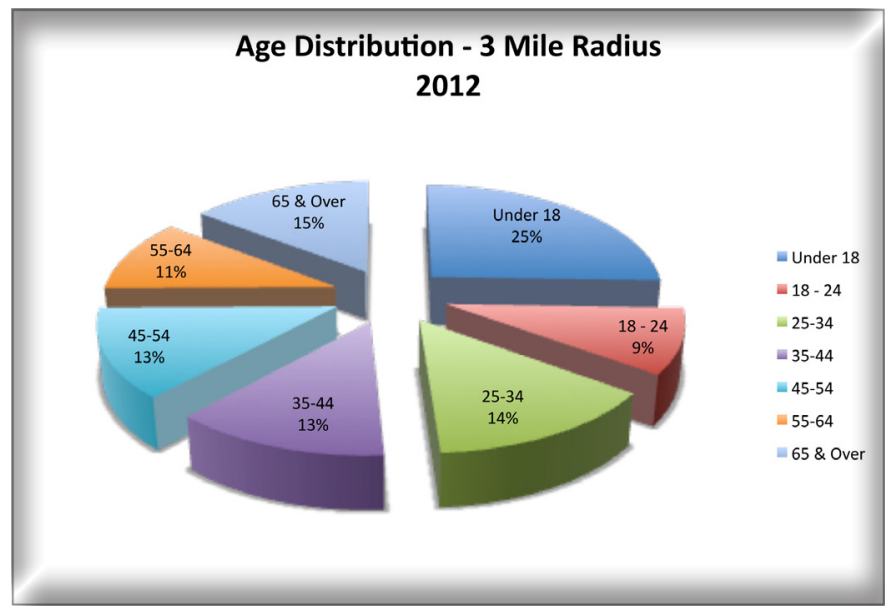

Figure 3.6

Area indicate that the demographic diversity will remain a strong asset in the near future.

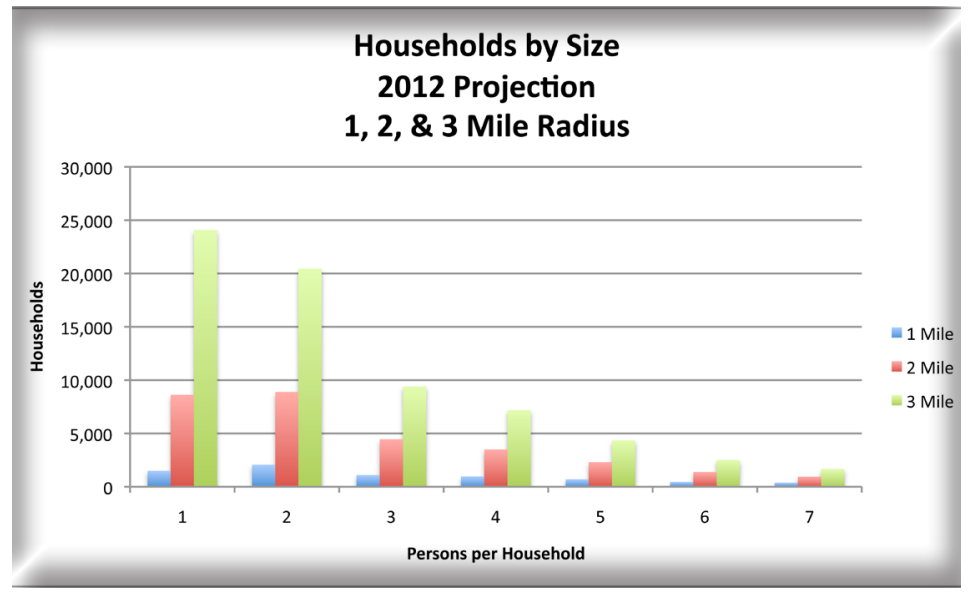

Figure 3.7

\begin{tabular}{|c|c|c|c|c|}
\hline \multicolumn{5}{|c|}{ FB Housing Tenure } \\
\hline \multicolumn{5}{|c|}{3 Mile Radius } \\
\hline Year & \multicolumn{2}{|c|}{2000} & \multicolumn{2}{|c|}{2007} \\
\hline & Units & $\%$ & Units & $\%$ \\
\hline Owners & 33,430 & 48 & 36,521 & 54 \\
\hline Renters & 36,521 & 52 & 30,708 & 46 \\
\hline Total & 69,951 & 100 & 67,229 & 100 \\
\hline
\end{tabular}

Source: MapInfo Corporation, 2008; JRC, 2009

Figure 3.8 


\begin{tabular}{|c|c|c|c|c|c|c|}
\hline \multicolumn{7}{|c|}{ FB Population By Race/Ethnicity } \\
\hline \multirow[t]{2}{*}{ Year } & \multicolumn{2}{|r|}{2000} & & \multicolumn{3}{|c|}{2007} \\
\hline & \multicolumn{5}{|c|}{ Radius } & \\
\hline Race & 1 Mile & 3 Mile & 5 Mile & 1 Mile & 3 Mile & 5 Mile \\
\hline White & 5,516 & 63,225 & 146,868 & 7,618 & 74,143 & 174,630 \\
\hline Black & 2,585 & 24,813 & 51,250 & 2,545 & 26,152 & 56,790 \\
\hline Asian/Hawaiian/Pacific Islander & 5,023 & 28,959 & 65,882 & 5,383 & 34,839 & 81,780 \\
\hline American Indian/Alaska Native & 260 & 1,530 & 2,648 & 292 & 1,687 & 3,070 \\
\hline Hispanic & 5,698 & 50,742 & 113,561 & 9,303 & 51,130 & 96,687 \\
\hline Other (2+ Races) & 862 & 8,328 & 17,254 & 6,134 & 34,370 & 64,187 \\
\hline Total: & 19,944 & 177,597 & 397,463 & 31,275 & 222,321 & 477,144 \\
\hline
\end{tabular}

Source: LoopNet, 2008; JRC, 2008

* Radius orginates from 5540 Franklin Boulevard, Sacramento, CA 95820

\section{Figure 3.9}

As indicated in figures 3.9 and 3.10, Hispanics are the fastest growing ethnic group in the Project Area and Sacramento County. The rapid increase in Hispanics creates the following opportunities for existing and future businesses:

- Hispanic centric auto accessory dealers -this may be one area in our current economy which may be increasing in sales as more people seek to prolong the life of their auto or to enhance the use of the vehicle in lieu of buying a new vehicle

- Eateries which cater to the diverse tastes of ethnic clientele

- Clothing stores which target ethnic youth
- National retailers -- As the Hispanic youth population expands along with their spending power, national retailers such as Target are willing to offer more products which are aimed at meeting the needs of ethnic consumers and will be more willing to locate stores in diverse ethnic areas

- Stores which focus on selling items for specific ethnic events, such as dresses for Quinceanera

*The next chapter covers the opportunities and challenges faced by communities as they cater to ethnic groups in an effort to revitalize the economic climate of their community

\begin{tabular}{|c|c|c|c|c|c|c|c|c|}
\hline \multicolumn{9}{|c|}{ BASELINE 2006 POPULATION PROJECTIONS SACRAMENTO COUNTY, 2000 - 2030} \\
\hline & \multicolumn{2}{|c|}{2000} & \multicolumn{2}{|c|}{2010} & \multicolumn{2}{|l|}{2020} & \multicolumn{2}{|l|}{2030} \\
\hline Race & Population & Percentage & Population & Percentage & Population & Percentage & Population & Percentage \\
\hline Not Hispanic, White & 721,885 & $59 \%$ & 746,974 & $51 \%$ & 764,684 & $47 \%$ & 775,149 & $43 \%$ \\
\hline Not White & 511,690 & $41 \%$ & 704,892 & $49 \%$ & 857,622 & $53 \%$ & $1,028,723$ & $57 \%$ \\
\hline Hispanic & 197,578 & $16 \%$ & 297,898 & $21 \%$ & 374,677 & $23 \%$ & 461,534 & $26 \%$ \\
\hline Asian & 137,630 & $11 \%$ & 183,156 & $13 \%$ & 217,548 & $13 \%$ & 254,563 & $14 \%$ \\
\hline Pacific Islander & 7,485 & $1 \%$ & 13,238 & $1 \%$ & 17,307 & $1 \%$ & 21,844 & $1 \%$ \\
\hline Black & 120,446 & $10 \%$ & 136,147 & $9 \%$ & 155,677 & $10 \%$ & 174,612 & $10 \%$ \\
\hline American Indian & 9,363 & $1 \%$ & 10,489 & $1 \%$ & 11,161 & $1 \%$ & 11,888 & $1 \%$ \\
\hline Multirace & 39,188 & $3 \%$ & 63,964 & $4 \%$ & 81,252 & $5 \%$ & 104,282 & $6 \%$ \\
\hline Total: & $1,233,575$ & & $1,451,866$ & & $1,622,306$ & & $1,803,872$ & \\
\hline
\end{tabular}

\section{Figure 3.10}


The 2007 retail sales volume (figure 3.11) data for the Project Area shows that within a 3 mile radius, automobile dealers generate the greatest volume with $\$ 302,712,874$. Supermarkets generate $\$ 208,520,884$ and restaurants bring in nearly $\$ 140,000,000$. The aforementioned retail sales volumes show the importance of car dealers, supermarkets, and restaurants to the fiscal health and overall well being of Franklin Boulevard.

Due to the current state of the national and global economy, new car dealerships have been severely impacted. One should expect the retail sales volume for automobile dealers to be much lower in the next few years. However, as consumers look to acquire substitutes for new vehicles, they tend to either buy used vehicles or maintain the ones they have. Fortunately, the majority of car dealerships located within the Project Area focus on offering affordable used vehicles to consumers.

Furthermore, there are several repair shops, tire stores, and automobile accessory retailers located in the Project Area. The 2007 retail sales volume data (figure 3.11) shows that within a 3 mile radius, auto parts/acc/repair stores bring in over $\$ 37,000,000$ for the local economy. The combination of used-car dealerships, repair shops, tire stores, and automobile accessory retailers should help the Project Area stave off some of the tremendous lossess suffered in other areas which have focused on selling more expensive vehicles.

The following chapter highlights opportunities and challenges faced by communities as they tranform their fiscal and physical environment. Information regarding how to effectively target ethnic clientele and the differences and similarities between the Project Area and the communities analyzed is provided.

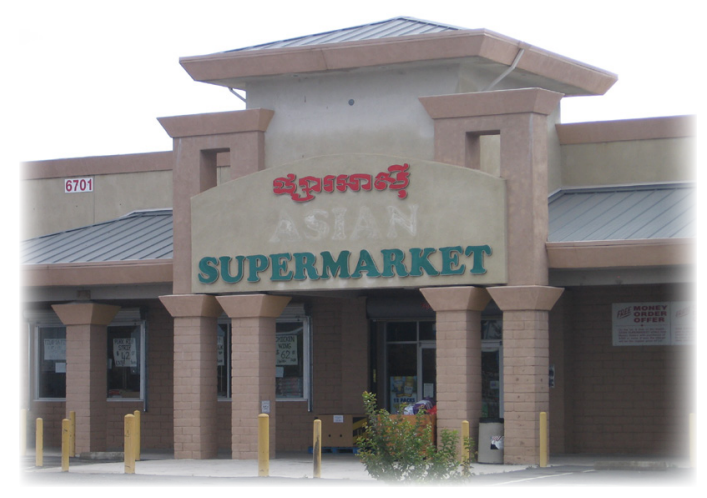


FB Retail Sales Volume

\begin{tabular}{|c|c|c|c|}
\hline & \multicolumn{3}{|c|}{ Radius } \\
\hline Retail Sales Volume & 1 Mile & 3 Mile & 5 Mile \\
\hline Children/Infants Clothing Stores & $\$ 1,683,733$ & $\$ 16,135,889$ & $\$ 37,167,150$ \\
\hline Jewelry Stores & $\$ 1,253,741$ & $\$ 12,105,015$ & $\$ 27,955,689$ \\
\hline Mens Clothing Stores & $\$ 2,759,060$ & $\$ 25,221,455$ & $\$ 57,188,990$ \\
\hline Shoe Stores & $\$ 2,524,644$ & $\$ 23,128,382$ & $\$ 52,458,509$ \\
\hline Womens Clothing Stores & $\$ 5,287,995$ & $\$ 46,552,543$ & $\$ 104,158,904$ \\
\hline Automobile Dealers & $\$ 31,554,484$ & $\$ 302,712,874$ & $\$ 689,862,488$ \\
\hline Automotive Parts/Acc/Repair Stores & $\$ 3,974,793$ & $\$ 37,293,426$ & $\$ 84,857,908$ \\
\hline Other Motor Vehicle Dealers & $\$ 1,226,818$ & $\$ 11,336,276$ & $\$ 25,730,246$ \\
\hline Tire Dealers & $\$ 1,038,506$ & $\$ 9,888,609$ & $\$ 22,663,641$ \\
\hline Hardware Stores & $\$ 394,129$ & $\$ 4,483,084$ & $\$ 10,409,553$ \\
\hline Home Centers & $\$ 3,638,171$ & $\$ 33,081,365$ & $\$ 73,279,824$ \\
\hline Nursery/Garden Centers & $\$ 1,043,252$ & $\$ 10,217,953$ & $\$ 23,565,373$ \\
\hline Outdoor Power Eqauipment Store & $\$ 384,123$ & $\$ 3,841,873$ & $\$ 8,679,869$ \\
\hline Paint/Wallpaper Stores & $\$ 140,245$ & $\$ 1,285,037$ & $\$ 2,848,366$ \\
\hline Appliance/TV/Other Electronics Stores & $\$ 3,058,976$ & $\$ 28,279,459$ & $\$ 64,568,834$ \\
\hline Camera/Photographic Supplies Stores & $\$ 513,028$ & $\$ 4,770,475$ & $\$ 10,803,840$ \\
\hline Computer/Software Stores & $\$ 1,649,913$ & $\$ 14,916,008$ & $\$ 33,467,739$ \\
\hline Beer/Wine/Liquor Stores & $\$ 1,858,001$ & $\$ 17,622,790$ & $\$ 40,415,984$ \\
\hline Convenience/Specialty Food Stores & $\$ 3,067,846$ & $\$ 28,967,983$ & $\$ 67,778,340$ \\
\hline Restaurant Expenditures & $\$ 12,819,109$ & $\$ 139,414,065$ & $\$ 325,241,540$ \\
\hline Supermarkets/Other Grocery excl Conv & $\$ 22,477,889$ & $\$ 208,520,884$ & $\$ 471,649,036$ \\
\hline Furniture Stores & $\$ 3,163,574$ & $\$ 29,506,371$ & $\$ 67,074,566$ \\
\hline Home Furnishing Stores & $\$ 1,946,456$ & $\$ 18,332,780$ & $\$ 41,966,149$ \\
\hline Gen Merch/Appliance/Furniture Stores & $\$ 28,580,889$ & $\$ 263,963,879$ & $\$ 598,354,360$ \\
\hline Gasoline Stations w/ Convenience Stores & $\$ 18,505,743$ & $\$ 165,636,005$ & $\$ 373,729,668$ \\
\hline Other Gasoline Stations & $\$ 15,437,898$ & $\$ 136,668,022$ & $\$ 305,951,331$ \\
\hline Department Stores excl Leased Depts & $\$ 31,639,863$ & $\$ 292,243,334$ & $\$ 662,923,190$ \\
\hline Genera Merchandise Stores & $\$ 25,417,313$ & $\$ 234,457,506$ & $\$ 531,279,791$ \\
\hline Other Health/Personal Care Stores & $\$ 2,092,459$ & $\$ 19,780,750$ & $\$ 44,811,037$ \\
\hline Pharmacies/Drug Stores & $\$ 10,874,497$ & $\$ 100,878,233$ & $\$ 227,993,850$ \\
\hline Pet/Pet Supplies Stores & $\$ 1,656,116$ & $\$ 14,858,093$ & $\$ 33,252,731$ \\
\hline Book/Periodical/Music Stores & $\$ 827,623$ & $\$ 6,046,825$ & $\$ 12,858,093$ \\
\hline Hobby/Toy/Game Stores & $\$ 737,192$ & $\$ 6,908,381$ & $\$ 14,851,105$ \\
\hline Musical Instrument/Supplies Stores & $\$ 282,990$ & $\$ 2,678,254$ & $\$ 6,105,000$ \\
\hline Sewing/Needlework/Piece Goods Stores & $\$ 125,066$ & $\$ 1,017,445$ & $\$ 2,216,650$ \\
\hline Sporting Goods Stores & $\$ 1,410,754$ & $\$ 13,673,856$ & $\$ 32,563,130$ \\
\hline Video Tape Stores - Retail & $\$ 253,978$ & $\$ 2,370,165$ & $\$ 5,395,544$ \\
\hline
\end{tabular}

Total:

$\$ 245,300,867 \quad \$ 2,288,795,344 \quad \$ 5,196,078,018$

Source: Loopnet, 2008; JRC, 2008

*Radius originates from 5540 Franklin Boulevard, Sacramento, CA 95820

Figure 3.11 
20 Franklin Boulevard Market Analysis

Page Intentionally Left Blank 


\section{Emerging Market Opportunities \& Case Studies}

As indicated in the previous section, ethnic populations have and will continue to emerge as an ever increasing segment of our society. Businesses have and will continue to target ethnic clientele to stay competitive in the marketplace. Businesses need to continually be cognizant of emerging market opportunities to retain a competitive edge, especially during tough economic times.

As the case studies provided in the end of this section will illustrate, businesses can become more than an instrument for financial profit. Businesses working together with government and community leaders can transform traditionally underserved communities physically, fiscally, and help create or enhance an existing community gathering place.

The adjacent column highlights the segregation that still exists in our society. While ethnic enclaves may

\section{Segregation Continues ....}

Martin Luther King once described Sunday mornings, when people go to church, as the most segregated moment in American life. That is probably still true. But, particularly for groups other than blacks, Saturday mornings are not far behind. A century ago ethnic-minority groups clustered for self-defence, or because they were forced to. Half a century ago they were bound together by language and poverty. Now they congregate to eat and shop.

Source: Economist.com, accessed on April 29, $2009 @$ http://www.economist.com/world/unitedstates/displayStory.cfm?story_id=12987556

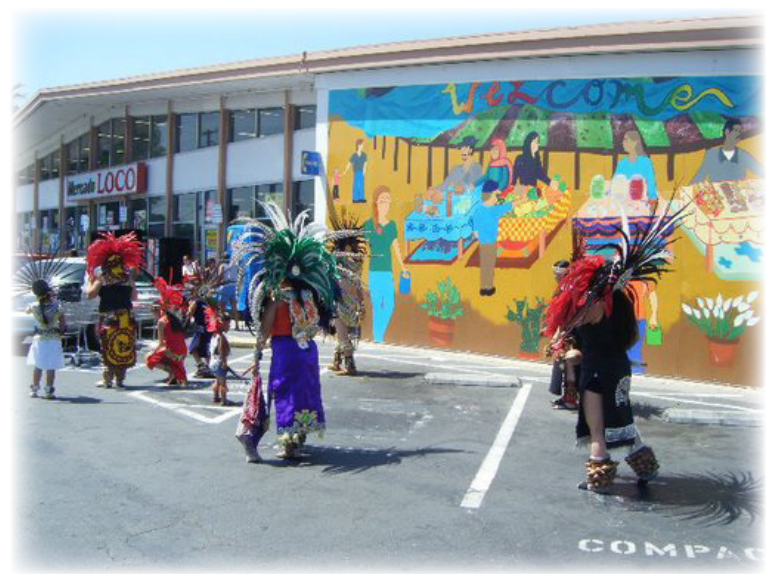


be gathering places utilized by one or two dominant ethnic groups, they can become cultural hubs utilized by all.

Franklin Boulevard's diversity coupled with access to SR 99 and regional transit will enhance the business community's abilitiy to capitalize on the existing ethnic diversity. While Franklin Boulevard is home to a diverse group of people, special attention needs to be placed on the Hispanic population which has thrived in the area for sometime.

The text boxes located on pages $21 \& 22$ focus on the value businesses may obtain by catering to Hispanics. Particular emphasis is placed on the burgeoning Hispanic youth demographic. According to Nielsen Media Research, "One in five teens in the United States (20\%) is of Hispanic descent. Between 1993 and 2001, the Hispanic teen population grew 30\%, while the non-Hispanic population grew $8 \%$ during the same period.

"Never doubt that a small group of thoughtful, committed citizens can change the world. Indeed, it is the only thing that ever has.

-- Margaret Mead

\section{Hispanics,}

The Largest Minority Group

The Hispanic population has now surpassed the African American population to become the largest minority group in the U.S. Its growth outpaced the general population by $60 \%$ in the last ten years alone, and by 2010 it is projected that this population will reach 56 million, and will account for $15 \%$ of the total U.S. population to become the second largest Hispanic population in the world.

The Hispanic Market is unique because it is comprised of several different segments yet has strong commonalities such as the Spanish language. For example, Hispanics prefer advertising messages and product information to be in Spanish, but colloquialisms and pronunciations can differ depending on country of origin. Facile and literal translations of general market campaigns can lead to incorrect representation of product and message because there are aspects of each segment's culture, slang, idiosyncrasies, and customs which should be communicated correctly.

Source: La Verdad Marketing \& Media. Sonoma County, CA Hispanic Market Snapshot, 2005. 


\section{GENERATION Ñ}

According to studies by Nielsen Media Research:

- One in five teens in the United States (20\%) is of Hispanic descent. Between 1993 and 2001, the Hispanic teen population grew $30 \%$, while the nonHispanic population grew $8 \%$ during the same period.

- By 2020, the Hispanic teen population is expected to grow $62 \%$ compared to $10 \%$ growth in the number of teens overall.

- Hispanic teens hold $\$ 19$ billion in spending power; most of this is spent on clothing and jewelry. Other areas to which Hispanic teens allocate this money include music and entertainment, food and snacks, savings, gas and automobile expenses, and gaming and hobbies.

- The average Hispanic teen spends $\$ 320$ a month, $4 \%$ more than the average non-Hispanic teen spends. Shopping malls (84\%), supermarkets $(80 \%)$, and discount chains $(78 \%)$ are the most popular retail destinations for teens of Hispanic descent.

Source: La Verdad Marketing \& Media. Sonoma County, CA Hispanic Market Snapshot, 2005.

\section{Marketing to Hispanic Youth}

From a product development and marketing perspective, building current brand loyalty with the 20-34 age group segments is important, but competitive advantage lies with those who can gain market share with the emerging Hispanic Youth.

One mistake that some businesses and organizations make is to conclude that Hispanics are only an influence in several markets or regions of the country. There is no doubt that certain states and metropolitan markets exceed most locations in the country when it comes to the sheer concentration of Hispanics. However, significant population shifts and other demographic factors are occurring that will create big implications; and big opportunities for marketers and general managers now consider the influence that the Hispanic population and especially Hispanic Youth will have on the general market in the decades ahead. There is very little argument that the Baby Boom generation had a significant impact on not only the U.S. economy and marketplace, but indeed the entire world.

Likewise, most marketing experts and economists agree that the Hispanic population will be a tremendous influence on the labor force, the marketplace, and become even more of an influence on the general market for things such as advertising, radio, television, telecommunications, cinema, branding, and new product development along with packaging.

Source: La Verdad Marketing \& Media. Sonoma County, CA Hispanic Market Snapshot, 2005. 


\section{Case Studies:}

The following case studies summarize development projects in ethnic commercial corridors, which exhibited one or more of the following attributes:

- Development catered to one or more minority groups through design and use

- Development involved community input

- Development serves as gathering place/ethnic enclave

- Development relied on public/ private partnership

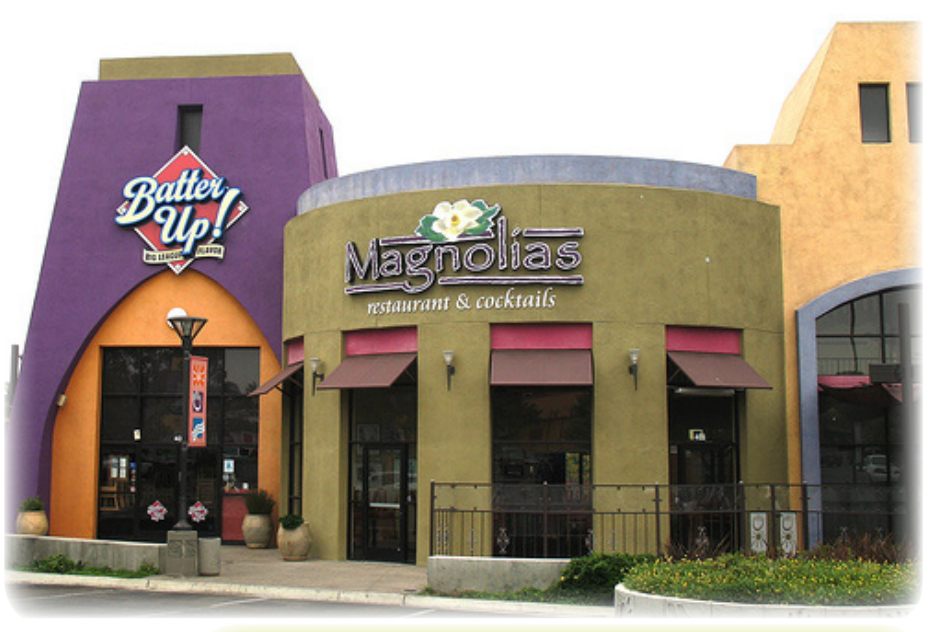

- Development became source of pride for ethnic group(s)

\section{Project Innovations}

\section{Market Creek Plaza, San Diego}

Market Creek Plaza is a 104,000 square foot commercial development on ten acres located in the center of San Diego's Diamond Neighborhoods. The plaza was developed on a former aerospace factory site by the Jacobs Center for Neighborhood Innovation (JCNI). The center is occupied by national retailers including Wells Fargo Bank, Starbucks, and Food-4-Less. Additional businesses include locally owned restaurants and also Where the Worlds Meet, which is a retailer specializing in catering to an ethnically diverse clientele. Plaza amenities include an amphitheater capable of seating 500 coupled with a floating stage. The amphitheatre serves as an excellent community gathering place.

On the surface, Market Creek Plaza appears to solely be an aesthetically pleasing commercial development paying homage to Mexican architecture, but it's much more.
- Development of an innovative network of community teams coming together to build a community vision

- Broad community involvement in design and development of a commercial project

- Creation of innovative program-related investment tools for social-purpose investors

- Design of an owner-builder, mentorprotege construction program which is comprehensive in scope and is providing a vehicle for more than half the project to be built by the neighborhood

Source: MarketCreekPlaza.com, accessed on April 25, 2009 @ http://www.marketcreek.com/mcp_project.html 
The plaza is an example of a physical and fiscal transformation, which has occurred within a traditionally underserved community. The pla$\mathrm{za}$ is the result of a relationship between private and public entities built on trust and mutual respect for one another (Please see the adjacent text box and the text boxes on pages $25 \& 26$ to garner a greater understanding of the social, cultural, and economic impacts resulting from the development of Market Creek Plaza).

From its inception, the development has relied upon a network of stakeholders working together to revitalize an underserved community through building community consensus and establishing in community members a sense of ownership never experienced before. In essence, the development has been an opportunity for residents to hone their construction skills and create an asset for the community.

\section{Community Ownership:}

In order to engender a sense of community and ownership of the development, a clear vision had to be established. To this end, hundreds of community meetings were held and over 800 neighborhood surveys were conducted in four languages. The consensus building clearly led to the understanding that the residents desired a development which served as a vibrant commercial and cultural hub for their community.

As momentum built, a variety of private and public entities came together. One of the key contributors was the Jacobs Center for Neighborhood Innovation (JNCI). JNCI is a nonprofit operating foundation supported by the Jacobs Family Foundation. JNCI served as the developer for Market Creek Plaza and helped obtain the $\$ 23.5$ million necessary for development.

The following quote from MarketCreekPlaza. com effectively states the overarching goal of the development process: "Community ownership of assets gives residents control of their future. Neighborhood revitalization linked with a strategy for local ownership eliminates blight, expands resources, and gives residents a way to

\section{Social and Cultural Impact}

- Chollas Creek restored (part of City's plan), natural vegetation, walking paths

- 500-seat outdoor amphitheater

- Unique architectural character created by multicultural team

- Multi-cultural values expressed in $\mathrm{MCP}$ through community art estimated at \$ 1.4 million

- Safe place for intergenerational and multi-ethnic interactions

Source: MarketCreekPlaza.com, accessed on April 25, 2009 @ http://www.marketcreek.com/mcp_project.html

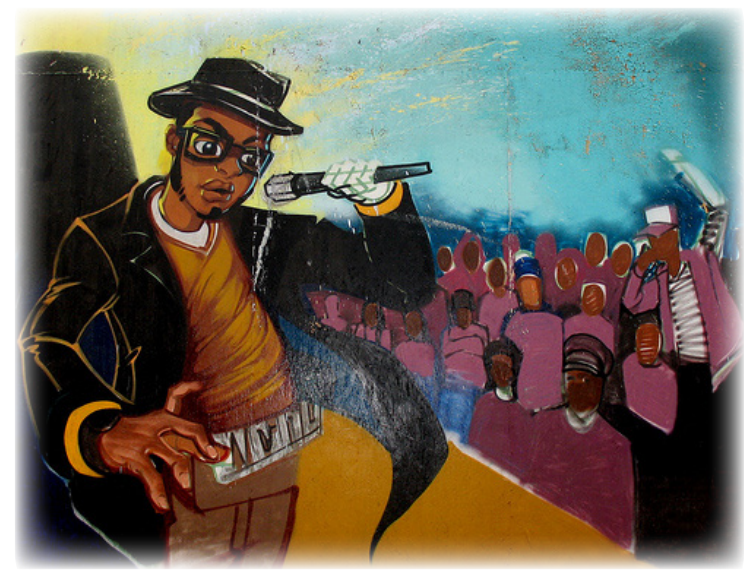


drive community change without being displaced by it."

Clearly, stakeholders recognized that the synergy derived from their teamwork led to a development which surpassed any development they could have created on their own. Business, government, and community leaders were able to transcend their differences in order to create a vibrant commercial and cultural hub for their community.

"You cannot escape the responsibility of tomorrow by evading it today." -- Abraham Lincoln

\section{Economic Impact}

- More than 1,700 new jobs in the neighborhood

- 360 construction jobs with training for emerging contractors, supported by contractor working lines of credit

- Nine working teams, involving thousands of residents and businesses, build skills in every aspect of project

- Community ownership strategy; hundreds of committed community residents investing their own capital in the project, building wealth by rebuilding their neighborhood

Source: MarketCreekPlaza.com, accessed on April 25, 2009 @ http://www.marketcreek.com/mcp_project.html

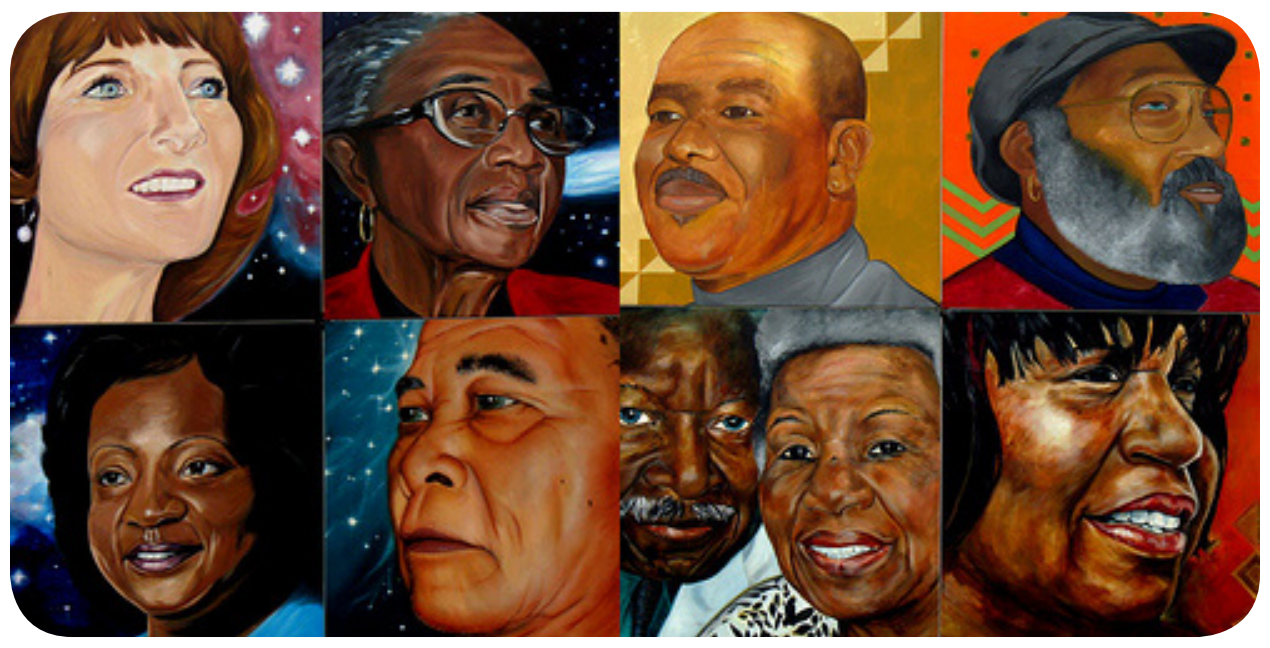




\section{Fruitvale Transit Village and Public Market, Oakland}

The Fruitvale Transit Village project is the product of community participation coupled with partnerships between public and private entities in order to revitalize a traditionally underserved minority community located in Oakland, California. The development is a result of several years of public participation and a substantial amount of public and private investment to become a reality. The Fruitvale Transit Village is a mixed-use development set beside the Fruitvale Bay Area Rapid Transit (BART) station. The infill development provides community members access to public transit while offering affordable housing to many. The Fruitvale Transit Village contains the following:

- 45,000 ft2 Retail/Restaurant Use

- 54,000 ft2 Nonprofit Health-Care Clinic

- 55,000 ft2 Child Care Facility

- 15,000 ft2 Library

- 45,000 ft2 Executive Offices

- 68 Units of HUD Housing

- 220 Units of Mixed-Income Housing

- 2 Parking Garages for 1,500 Cars

\section{Community Participation:}

The Fruitvale Development Corporation (FDC), which is a subsidiary of the nonprofit Unity Council, developed the project. In 1991, a plan to build a parking structure on the site spurred community opposition and eventually led to the parking structure being scrapped in favor of the current development. Community members feared that the parking structure would be a detriment to their community by increasing traffic, pollution, and severely cutting pedestrian access to the transit system. Due to the public outcry, BART decided to work with the Unity Council to create a transit vil-

\section{Snapshot of Fruitvale \\ Community}

Location: Southeast of downtown Oakland

Population: 53,000

\section{Racial and Ethnic Composition:}

- Latino - 52 percent

- Asian/Pacific Islanders - 23 percent

- African American - 16 percent

- White - 7 percent

- Native American - 2 percet

- Other - 1 percent

\section{Average Household Income:} $\$ 36,266$

Source: 1990 U.S. Census. Passage collected from United States Department of Transportation Federal Highway Administration - Federal Transit Administration. Data accessed @ http://www.fhwa. dot.gov/environment/ejustice/case/case6.htm on May 15, 2009.

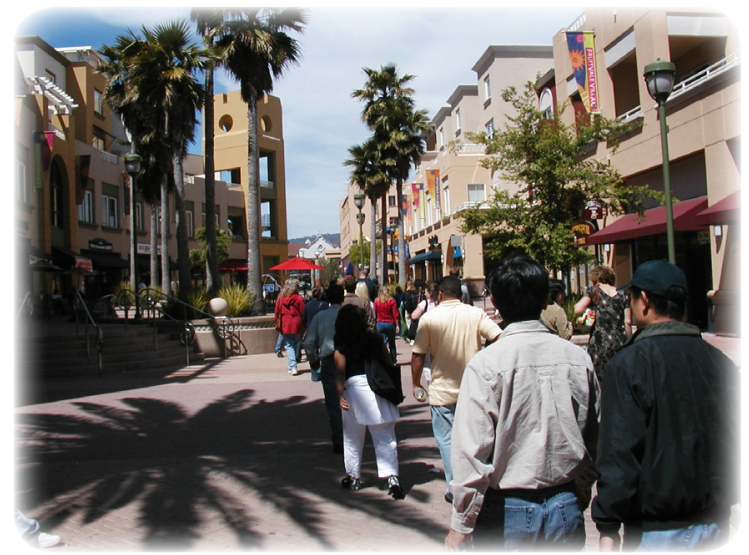


lage, which relied upon public participation to establish a vision for the project geared towards meeting the diverse needs of the community.

\section{Creative Financing:}

Through years of public visioning and planning workshops, the parameters for the Fruitvale Transit Village were established. The Unity Council was able to secure $\$ 185,000$ in Community Development Block Grant (CDBG) funds through the City of Oakland to conduct community workshops. In addition to recieving CDBG funds, the Unity Council garnered support from myriad public and private agencies to raise capital via the use of creative financing in order to make the development a reality. The Unity Council also received a $\$ 2.3$ million grant from the Federal Transportation Administration's Livable Communities Initiative.

In addition to creative financing and community efforts, the following participants working together as a cohesive unit made the Fruitvale Transit Village possible:

\section{- The Unity Council}

- National Transit Access Center, University of California at Berkeley

- Bay Area Rapid Transit District (BART)

- City of Oakland

- Metropolitan Transportation Commission

- Federal Transit Administration

- U.S. Department of Housing \& Urban Development (HUD)

- U.S. Environmental Protection Agency (EPA)

\section{Conclusion:}

The presence of the transit facilities play an integral role in giving community residents increased access to shopping, jobs, medical care, and other key resources. The Fruitvale

\section{What is Transit-Oriented Development?}

Transit-Oriented Development (TOD) is a simple concept: moderate and high density housing, along with complementing public uses, jobs, retail and services, are concentrated in mixeduse developments located at strategic points along the regional transit system. Each TOD has a centrally located transit stop and core commercial area; accompanying residential and/or employment uses are within an average 2,000 feet walking distance. The location, design, configuration, and mix of uses in a TOD provides an alternative to current suburban development trends by emphasizing a pedestrianoriented environment and reinforcing the use of public transportation.

This linkage between land use and transit is designed to result in an efficient pattern of development that supports the transit system and makes significant progress in reducing sprawl, traffic congestion, and air pollution. The TOD's mixed-use clustering of land uses within a pedestrianfriendly area connected to transit provides for growth with a minimum of environmental and social costs.

Source: Excerpts from 1000 Friends of Oregon, The LUTRAQ Alternative: Volume 3 (1992), p. 8. Passage collected from United States Department of Transportation - Federal Highway Administration - Federal Transit Administration. Data accessed @ http://www. fhwa.dot.gov/environment/ejustice/case/case6.htm on May 15, 2009. 
Transit Village illustrates how the combination of community participation, private/public partnerships, and transit-oriented development can spur economic revitalization in traditionally underserved low-income urban communities. The text box below from the U.S. Department of Transportation - Federal Highway Administration displays the project chronology for Fruitvale Transit Village.

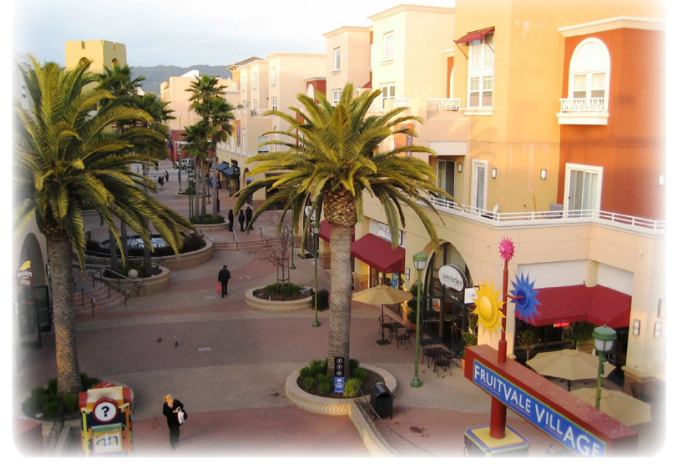

\section{Project Chronology}

- 1991 - BART announces plans to build a multi-level parking facility at the Fruitvale rapid transit station. The Fruitvale community opposes the project.

- February 1992 - The Unity Council receives $\$ 185,000$ in Community Development Block Grant funds to develop an alternative plan for the station.

- April 1993 - The Unity Council is awarded a $\$ 470,000$ Federal Transit Administration (FTA) planning grant.

- May 1993 - The National Transit Access Center at UC Berkeley and the Unity Council hold a community design symposium.

- July 1994 - The Unity Council, BART, and City of Oakland sign a Memorandum of Understanding to form the Fruitvale Policy Committee.

- Spring/Summer 1995 - The Unity Council holds a series of community site planning meetings.

- 1996 - The City of Oakland passes a zoning ordinance capping parking space construction in the Transit Village area.

- 1997 - The Unity Council creates the Fruitvale Development Corporation (FDC).

- 1998 - The Unity Council gains control of the Village site through a land swap with BART.

- September 1999 - BART receives $\$ 7.3$ million from the FTA to build replacement parking near the Fruitvale station.

- September 1999 - Groundbreaking for construction of the Fruitvale Transit Village project takes place.

Source: Passage collected directly from United States Department of Transportation - Federal Highway Administration - Federal Transit Administration. Data accessed @ http://www.fhwa.dot.gov/environment/ejustice/case/case6.htm on page 6 on May 15, 2009. 


\section{Case Studies Conclusion:}

The aforementioned case studies possess similarities and differences to the Project Area.The following are similarities and differences between the Project Area and either case studies:

\section{Similarities:}

- Traditionally underserved ethnic community seeking to tranform the fiscal and physical environment

- Poor public perception regarding safety

- Proximity to lightrail (Fruitvale)

- Community involvement

- Private/Public Partnerships

- Need for enhanced infrastructure

- Need for financial capital

\section{Differences:}

- Geographic location

- Large land parcel (40+ acres) available for development (Market Creek Plaza)

- Each community has their own history and identity

Despite the differences between the Project Area and the communities analyzed in the case studies, stakeholders can build upon the lessons learned from Market Creek Plaza and the Fruitvale Transit Village.

Market Creek Plaza is an example of how a traditionally underserved area can be transformed through private/public partnerships and most importantly community involvement. By creating safe places for intergenerational and multi-ethnic interactions, we will become a more inclusive society. Hopefully, future generations will value and appreciate the differing cultures that exist in our society.
The presence of the transit facilities played an integral role in giving community residents increased access to shopping, jobs, medical care, and other key resources. The Fruitvale Transit Village illustrates how the combination of community participation, private/public partnerships, and transit-oriented development can spur economic revitalization in traditionally underserved low-income urban communities.

\section{Lessons Learned:}

Community-based organizations can be used as effective instruments to identify community preferences, needs, and concerns. Communitybased organizations are usually a better alternative than government agencies to truly determine whether or not a project is appropriate for a given community. Input provided by community driven organizations is a good barometer for how well the proposed project will be received by the community at large.

The concept for the Fruitvale Transit Village originated within the Fruitvale community, following a proposal by BART to construct a parking garage at the Fruitvale BART station. That proposal generated little community support. Fortunately, BART altered plans once it recognized the community's desire for a different type of project which needed to ge developed through a more inclusive planning process.

The development of Market Creek Plaza relied heavily upon the input of communitiy members to create a place which served the business community. The development also provided a much needed community gathering place.

Partnerships can be an effective tool for overcoming barriers posed by the expense and complexity of certain projects. The Fruitvale Transit Village and Market Creek Plaza developments survived various legal, financial, and regulatory challenges in large part because of the leadership of organizations such as the Unity Council and the Jacobs Center for Neighborhood Innovation. The projects also benefited from the willingness of key players like BART and the 
City of San Diego to actively participate in the development process.

Public transit facilities are valuable assets for certain low-income, minority communities in urban locations. The Project Area needs to take advantage of the presence of light rail. Such facilities are essential to providing community members increased access to jobs, shopping, and other key destinations. As in the case of the Fruitvale Transit Village, transit facilities may serve as anchors for neighborhood revitalization.

\section{Challenges:}

The planning and design phase of Market Creek Plaza and the Fruitvale Transit Village featured strong community participation, effective leadership, and a willingness on the part of key public agencies to participate in a community-based planning process.

One of the main challenges in garnering the levels of community participation involved is providing community members adequate access to the planning process. Adequate access should include workshops at varying days and times to ensure that employed community members have the opportunity to partake in the planning process. Information should also be present in the native tongue of community members as a way to invite the community to participate.

In addition to community members, other stakeholders such as SHRA, City of Sacramento, County of Sacramento, and the NFDBA need to share the same goals and objectives for the Project Area. Community members will become confused and alienated if they are receiving mixed messages from public agencies. Public agencies will also need to possess a shared vision for the community in order to efficiently disperse the scarce resources that they possess.

Another challenge is transforming the physical environment in a way which revitalizes the community. The physical environment ranges from buildings to streetscapes and also to improved signage. The improvements should celebrate the history and diversity of Franklin Boulevard in a distictive way. Visitors should "feel" that they're in an attractive and unique place when they visit the area. The tranformation will require high levels of creativity and teamwork to become a reality. TOD should be carefully designed with input from stakeholders.

Public perception is a challenge faced by most traditionally underserved ethnic communities. The community will need to overcome some of the previously mentioned challenges before they are able to fully address public perception. As the tranformation process occurs, local media should be encouraged to highlight the process. Positive community events which encourage the general public to participate will also be important in changing public perception.

As the Project Area transforms, public officials and community leaders need to be on the lookout for signs of gentrification and be prepared to work together on a plan to mitigate damages due to displacement of long time residents. The goal is to tranform the area so that existing and future residents can cohexist together in harmony. 
32 Franklin Boulevard Market Analysis

Page Intentionally Left Blank 


\section{Conclusion}

Franklin Boulevard is an unique community which has opportunities and challenges based on its fiscal and physical environments. The previous chapters touched upon how community stakeholders can harness their resources together to take advantage of existing and future opportunities while addressing existing challenges. The following recommendations serve as an opportunity for stakeholders to come together to determine which actions would be best for the community. Some of the recommendations are already in place, while others have yet to be explored.

\section{Recommendations:}

- Specific efforts to recruit businessess that specialize in catering to Hispanic youth

- Events that highlight Franklin Boulevard's diversity -- farmer's market and art and crafts fair

- Art exhibits which celebrate Franklin Boulevard's history and/or diversity

- Improved signage

- Improved streetscapes

- Seek to increase transit oriented development (TOD) due to proximity to lightrail

- Target developers familiar with the needs of diverse communities -- prominent developers include Canyon-Johnson and Hispanic Retail Group (HRG)

- Create Website highlighting the business opportunities and events happening on Franklin Boulevard

- Form stronger partnerships with county and city police

- Invite local media to cover the positive changes that are going on

- Develop stronger relationship with code enforcement

- Improve building facades

- Form a committee to focus on using art as an attraction to draw in consumers

Some of these recommendations are already taking place and should be strengthened, while others will require more time before stakeholders can act upon them. Even though certain recommendations will rely on the expertise of specific stakeholders; all stakeholders should be involved in the process. In order to transform the Project Area into an "urban" destination for residents of the Sacramento region, all stakeholders need to harness their resources and expertise to ensure 
that resources are allocated efficiently.

The case studies provided in the previous section show the tremendous value of having a willing and able group of public and private entities working together. The presence of the transit facilities played an integral role in giving community residents increased access to shopping, jobs, medical care, and other key resources.

The Fruitvale Transit Village is an excellent example of how the combination of community participation, private/public partnerships, and transit-oriented development can spur economic revitalization in traditionally underserved low-income urban communities. The development of Market Creek Plaza relied heavily upon the input of communitiy members to create a place which served the business community. The development also provided a much needed community gathering place.

Clearly, stakeholders recognized that the synergy derived from their teamwork led to a development which surpassed any development they could have created on their own. Business, government, and community leaders were able to transcend their differences in order to create a vibrant commercial and cultural hub for their community

Partnerships are a necessary and effective tool for overcoming barriers posed by the expense and complexity of projects. Plans to revitalize communites such as those in the Project Area, will likely face various legal, financial, and regulatory challenges. All stakeholders will have to come together to overcome such barriers.

Any future plans for large scale development should take advantage of existing transportation infrastructure. Public transit facilities are valuable assets for certain low-income, ethnic communities in urban locations. Transit facilities are essential to providing community members increased access to jobs, shopping, and other key destinations. As in the case of the Fruitvale Transit Village, transit facilities may serve as anchors for neighborhood revitalization.

Ultimately, community members, SHRA, City of Sacramento, County of Sacramento, and the NFDBA need to share the same goals and objectives for the Project Area. Community members will become confused and alienated if they are receiving mixed messages from public agencies. Public agencies will also need to possess a shared vision for the community in order to efficiently disperse the scarce resources that they possess. The following page highlights strategies that specific stakeholders should focus their talents and efforts on. Establishing specific roles for stakeholders is neccessary to ensure that available resources are being maximized. Despite the immense challenges, the stakeholders of Franklin Boulevard can overcome them and transform the area into an "urban" destination for the Sacramento region. 


\section{Strategic Recommendations for Stakeholders}

\section{NFDBA}

- Events that highlight Franklin Boulevard's diversity -- farmer's market and arts and crafts fair

- Art exhibits which celebrate Franklin Boulevard's history and diversity

- Create website highlighting the business opportunities and events on Franklin Boulevard

- Establish regularly scheduled tabletop meeting with county and city police

- Collaborate with SHRA, the City of Sacramento, and County of Sacramento with formulating a list of specific public grants/loans to apply for

\section{SHRA}

- Seek public funds to enhance physical environment -- building facades, streetscapes, and general landscape

- Ehance stakeholder's (NFDBA and small business owners) ability to obtain public funds (workshops, personal assistance completing grant applications)

- Collaborate with NFDBA, City of Sacramento, and County of Sacramento with formulating a list of specific public grants/loans to apply for

\section{City of Sacramento}

- Collaborate with SHRA, NFDBA, and County of Sacramento with formulating a list of key targets for public grants/loans to apply for

- Coordinate with NFDBA to produce events that highligh Franklin Boulevard's diversity -farmer's market, arts and crafts fair, and possible tie in with 2nd Saturday event

- Assist NFBDA with attracting developers that specialize in working in diverse communities, especially for those focused on transit oriented development (TOD)

\section{County of Sacramento}

- Collaborate with SHRA, NFDBA, and City of Sacramento with formulating a list of key targets for public grants/loans to apply for

- Assist NFBDA with attracting developers that specialize in working in diverse communities, especially for those focused on transit oriented development (TOD)

- Assist NFBDA with utilizing media to highlight bussiness opportunities and events happening on Franklin Boulevard -- the County should work with NFDBA to determine which form(s) of media (print, televison, radio, \& internet) are most effective in drawing people into the area 


\section{Bibliography}

Bay Area Economics, Florin Road Master Plan Market Opportunities. September 2008.

Carter-Burgess, Franklin Boulevard Urban Design Master Plan. January 2001

CBRE Market View First Quarter 2009. Accessed on April 2, 2009 @ http://www.rocklin.ca.us/ businesses/business_resources/publications/real_estate_market_reports/cbre_market_view.asp

Dipasquale, D. and Wheaton, W.C. 1996. Urban Economics and Real Estate Markets. Inglewood Cliffs, N.J.: Prentice Hall. (Chapter 1: The Property and Capital Markets).

Economics Research Associates, Franklin Boulevard Redevelopment Project Area Market Analysis and Implementation Strategy 2004 - 2009. November 2004 Project No. 15387

Economist.com. Data accessed on April 29, 2009 @ http://www.economist.com/world/unitedstates/displaystory.cfm?story_id=12987556

Goldberg, M. and Chinloy, M. 1984. Urban Land Economics. New York: John Wiley. (Chapter 4: The Demand for Land).

Heikkila, Eric 2000. The Economics of Planning. New Jersey: Center for Urban Policy Research, Rutgers. (Chapter 4)

High Points Consulting, North Franklin District Strategic Plan 2008.

La Verdad Marketing \& Media. Sonoma County, CA Hispanic Market Snapshot, 2005.

Loopnet.com. http://www.loopnet.com

Mapinfo.com. http://www.mapinfo.com

MarketCreekPlaza.com, accessed on April 25,2009@ http://www.marketcreek.com/mcp_project.html

Neighborhoods.org. http://www.neighborhoods.org

Pulley, Michael. Sacramento Business Journal. Data accessed July 24, 2006 @ http://sacramento. bizjournals.com/sacramento/stories/2006/07/24/focus1.html

State of California, Department of Finance, Race/Ethnic Population with Age and Sex Detail, 2000-2050. Data accessed @ http://www.dof.ca.gov/HTML/DEMOGRAP/Data/RaceEthnic/ Population-00-50.php

U.S. Census, 1990. Passage collected from United States Department of Transportation-Federal Highway Administration - Federal Transit Administration. Data accessed @ http://www.fhwa. dot.gov/environment/ejustice/case/case6.htm on May 15, 2009 
Page Intentionally Left Blank 


\section{Appendices}




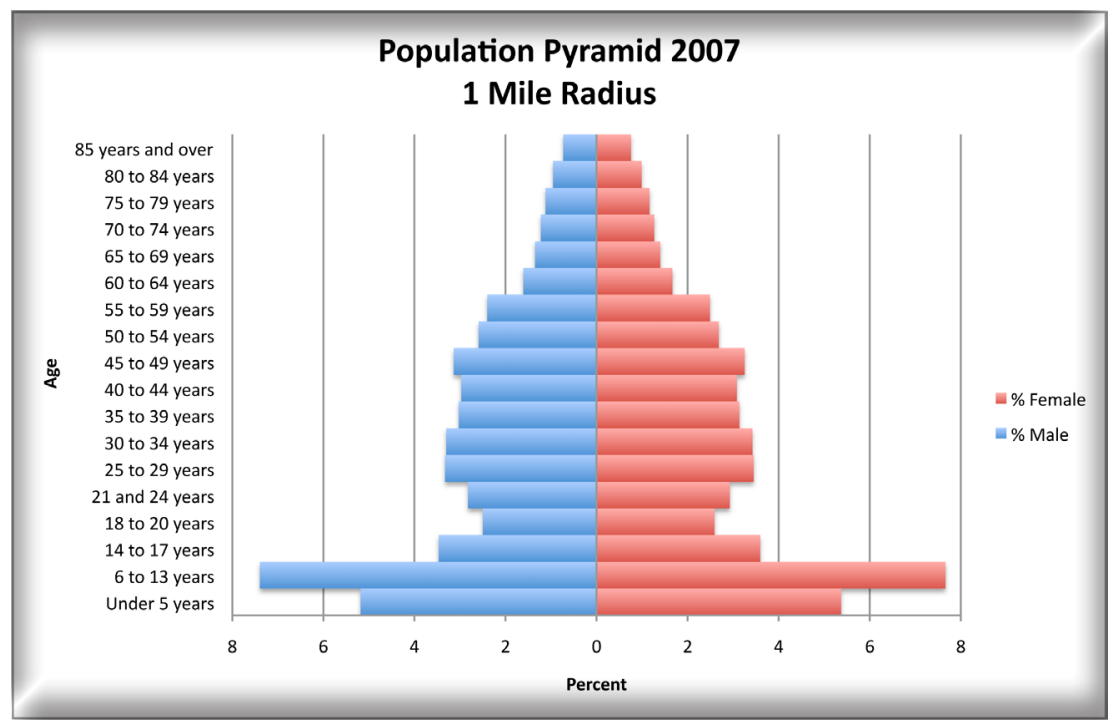

Figure 6.1

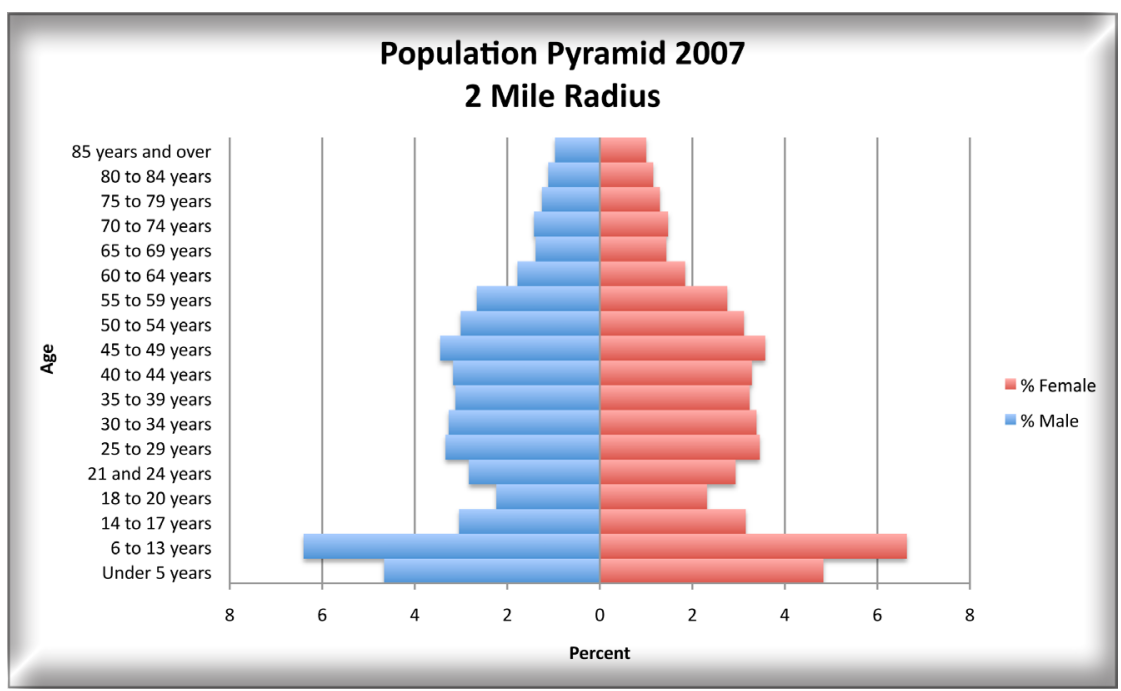

Figure 6.2 


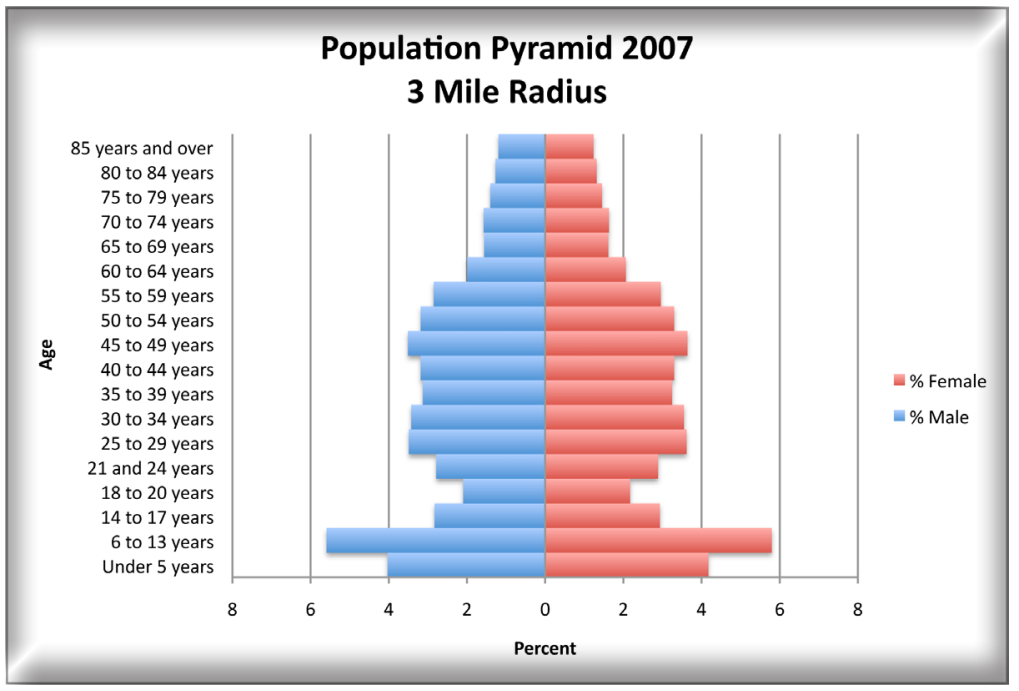

Figure 6.3

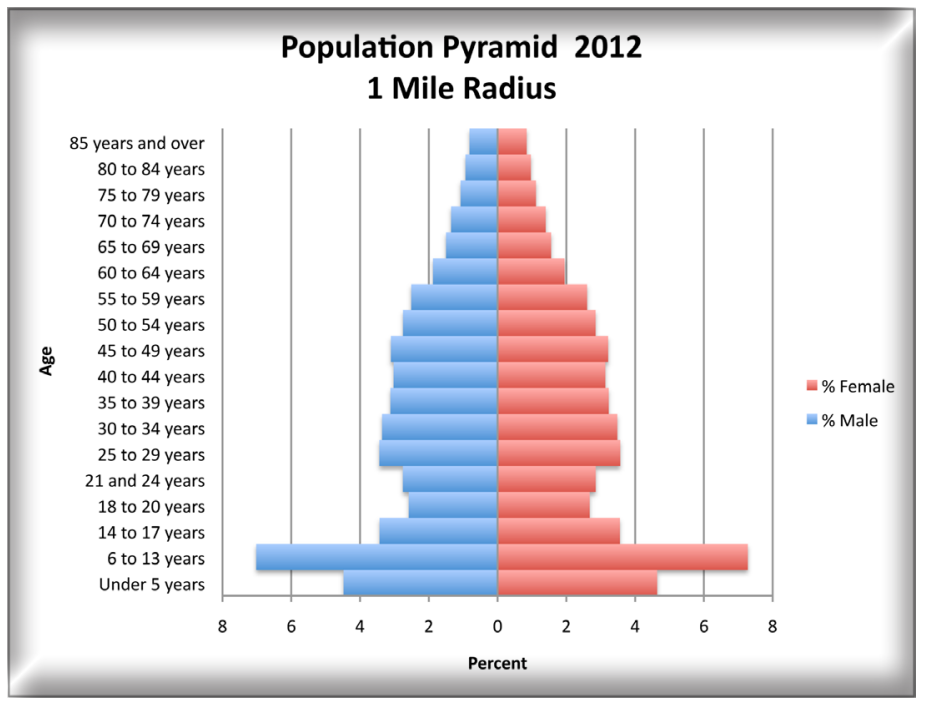

Figure 6.4 


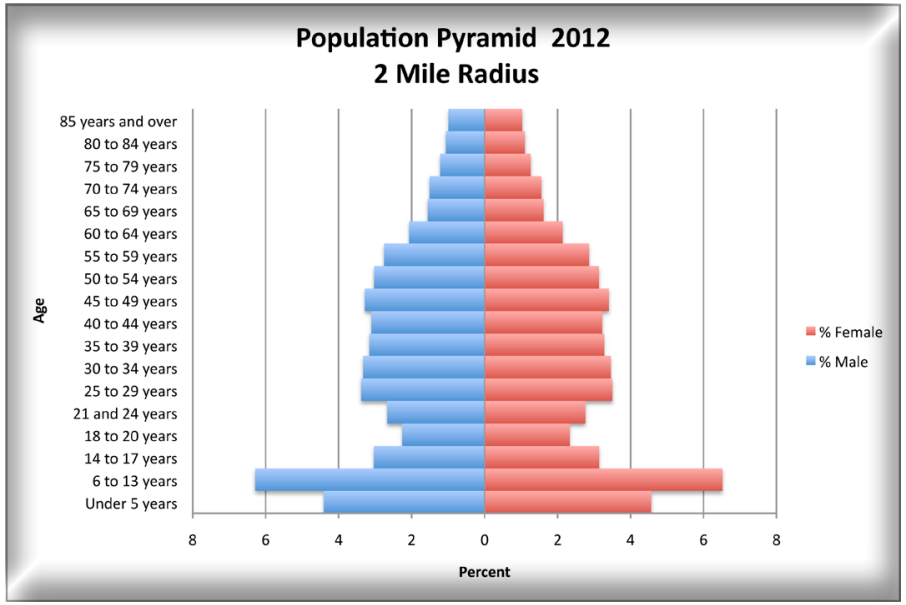

\section{Figure 6.5}

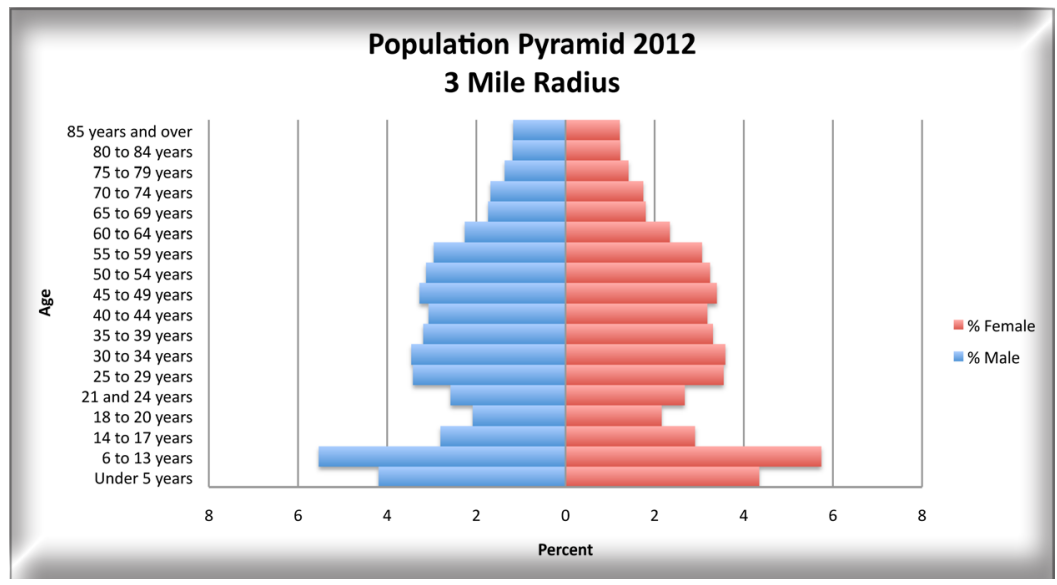

Figure 6.6 


\begin{tabular}{lccc}
\hline \multicolumn{4}{c}{ FB Household By Income Distritbution, 2007} \\
\hline \multicolumn{4}{c}{ Radius } \\
\hline Income & 1 Mile & 2 Mile & 3 Mile \\
\hline & 787 & 3,197 & 6,230 \\
$<\$ 10,000$ & 512 & 2,272 & 4,818 \\
$\$ 10,000-\$ 14,999$ & 577 & 2,170 & 4,814 \\
$\$ 15,000-\$ 19,999$ & 623 & 2,190 & 4,651 \\
$\$ 20,000-\$ 24,999$ & 556 & 1,869 & 4,332 \\
$\$ 25,000-\$ 29,999$ & 592 & 2,210 & 4,725 \\
$\$ 30,000-\$ 34,999$ & 548 & 2,010 & 4,378 \\
$\$ 35,000-\$ 39,999$ & 495 & 1,962 & 4,295 \\
$\$ 40,000-\$ 44,999$ & 381 & 1,667 & 3,792 \\
$\$ 45,000-\$ 49,999$ & 665 & 2,643 & 6,133 \\
$\$ 50,000-\$ 59,999$ & 558 & 2,948 & 7,294 \\
$\$ 60,000-\$ 74,999$ & 434 & 2,074 & 6,225 \\
$\$ 75,000-\$ 99,999$ & 149 & 890 & 2,556 \\
$\$ 100,000-\$ 124,999$ & 9 & 415 & 1,254 \\
$\$ 125,000-\$ 149,999$ & 29 & 219 & 797 \\
$\$ 150,000-\$ 199,999$ & 12 & 142 & 214 \\
$\$ 200,000-\$ 249,999$ & 35 & 272 & 669 \\
$\$ 250,000-\$ 499,999$ & 1 & 8 & 15 \\
$\$ 500,000+$ & & & \\
\hline
\end{tabular}

Source: MapInfo Corporation, 2008; JRC, 2009

Figure 6.7

FB Households by Size, 2007

\begin{tabular}{cccc}
\hline Persons & \multicolumn{3}{c}{ Radius } \\
\hline & 1 Mile & 2 Mile & 3 Mile \\
1 & 1,393 & 7,912 & 22,118 \\
2 & 1,963 & 8,584 & 19,829 \\
3 & 1,076 & 4,414 & 9,341 \\
4 & 983 & 3,578 & 7,308 \\
5 & 717 & 2,346 & 4,422 \\
6 & 462 & 1,399 & 2,546 \\
$7+$ & 371 & 924 & 1,629 \\
& & & \\
\hline
\end{tabular}

Source: MapInfo Corporation, 2008; JRC, 2009

Figure 6.8 
FB Households by Size, 2012

\begin{tabular}{cccc}
\hline \multicolumn{3}{c}{ Radius } \\
\hline Persons & 1 Mile & 2 Mile & 3 Mile \\
\hline 1 & 1,498 & 8,611 & 24,066 \\
2 & 2,063 & 8,881 & 20,448 \\
3 & 1,091 & 4,445 & 9,404 \\
4 & 963 & 3,499 & 7,175 \\
5 & 703 & 2,306 & 4,346 \\
6 & 454 & 1,376 & 2,501 \\
$7+$ & 379 & 950 & 1,668 \\
\hline
\end{tabular}

Source: MapInfo Corporation, 2008; JRC, 2009

Figure 6.9

\begin{tabular}{cccc}
\hline \multicolumn{4}{c}{ FB Total Households } \\
\hline \multicolumn{4}{c}{ Radius } \\
\hline Year & 1 Mile & 2 Mile & 3 Mile \\
\hline & & & \\
1990 & 6,975 & 27,313 & 62,209 \\
2000 & 6,953 & 27,676 & 63,377 \\
2007 & 6,965 & 29,158 & 67,193 \\
2012 & 7,151 & 30,067 & 69,608 \\
& & &
\end{tabular}

Source: MapInfo Corporation, 2008; JRC, 2009

Figure 6.10 
FB Household By Income Distritbution, 2012

\begin{tabular}{lccc}
\hline & \multicolumn{3}{c}{ Radius } \\
\hline Income & 1 Mile & 2 Mile & 3 Mile \\
\hline$<\$ 10,000$ & 719 & 2,963 & 5,792 \\
$\$ 10,000-\$ 14,999$ & 442 & 2,068 & 4,377 \\
$\$ 15,000-\$ 19,999$ & 517 & 1,986 & 4,297 \\
$\$ 20,000-\$ 24,999$ & 564 & 2,058 & 4,201 \\
$\$ 25,000-\$ 29,999$ & 524 & 1,752 & 3,960 \\
$\$ 30,000-\$ 34,999$ & 583 & 2,028 & 4,267 \\
$\$ 35,000-\$ 39,999$ & 518 & 1,859 & 4,063 \\
$\$ 40,000-\$ 44,999$ & 510 & 1,951 & 4,212 \\
$\$ 45,000-\$ 49,999$ & 428 & 1,773 & 3,890 \\
$\$ 50,000-\$ 59,999$ & 796 & 2,959 & 6,623 \\
$\$ 60,000-\$ 74,999$ & 714 & 3,610 & 8,566 \\
$\$ 75,000-\$ 99,999$ & 505 & 2,612 & 8,067 \\
$\$ 100,000-\$ 124,999$ & 224 & 1,201 & 3,499 \\
$\$ 125,000-\$ 149,999$ & 22 & 550 & 1,799 \\
$\$ 150,000-\$ 199,999$ & 32 & 264 & 997 \\
$\$ 200,000-\$ 249,999$ & 9 & 120 & 249 \\
$\$ 250,000-\$ 499,999$ & 40 & 293 & 720 \\
$\$ 500,000+$ & 4 & 20 & 27 \\
& & &
\end{tabular}

Source: MapInfo Corporation, 2008; JRC, 2009

Figure 6.11 


\begin{tabular}{|c|c|c|c|c|c|}
\hline \multicolumn{6}{|c|}{$\begin{array}{l}\text { CB RICHARD ELLIS } \\
\text { MARKET VIEWS } \\
\end{array}$} \\
\hline \multicolumn{6}{|c|}{ (In Areas Within and Adjacent to the Franklin Boulevard Redevelopment Project Area) } \\
\hline \multicolumn{6}{|c|}{$\begin{array}{l}\text { OFFICE } \\
\qquad \text { Area } 74 \text { (South Sacramento) }\end{array}$} \\
\hline & $\begin{array}{l}\text { Leasable } \\
\text { (Sq.Ft.) }\end{array}$ & $\begin{array}{l}\text { Vacant } \\
\text { (Sq.Ft.) }\end{array}$ & Vacancy Rate & $\begin{array}{l}\text { Absorption } \\
\text { (Sq,Ft.) }\end{array}$ & $\begin{array}{l}\text { Lease Rates } \\
\left(\mathrm{Sq}, \mathrm{Ft}_{\mathrm{t}}\right)\end{array}$ \\
\hline Third Quarter 2004 & $2,260,006$ & 111,803 & $8.87 \%$ & 46,931 & $\$ 1.40$ \\
\hline First Quarter 2009 & $1,408,664$ & 183,587 & $13.03 \%$ & 3,727 & $\$ 1.95$ \\
\hline Percent Change & $37.67 \%$ & $64.21 \%$ & $4.16 \%$ & $92.06 \%$ & $39.29 \%$ \\
\hline \multicolumn{6}{|c|}{$\begin{array}{l}\text { Retail } \\
\quad \text { Area } 17 \text { (South Sacramento) }\end{array}$} \\
\hline & $\begin{array}{l}\text { Leasable } \\
\text { (Sq.Ft.) }\end{array}$ & $\begin{array}{l}\text { Vacant } \\
\text { (Sq.Ft.) }\end{array}$ & Vacancy Rate & $\begin{array}{l}\text { Absorption } \\
\text { (Sq.Ft.) }\end{array}$ & $\begin{array}{l}\text { Lease Rates } \\
\text { (Sq.Ft.) }\end{array}$ \\
\hline Third Quarter 2004 & $4,155,157$ & 199,962 & $4.30 \%$ & 108,851 & $\$ 1.19$ \\
\hline First Quarter 2009 & $4,490,563$ & 481,208 & $10.70 \%$ & 114,512 & $\$ 1.64$ \\
\hline Percent Change & $8.07 \%$ & $140.65 \%$ & $6.40 \%$ & $5.20 \%$ & $37.82 \%$ \\
\hline \multicolumn{6}{|c|}{$\begin{array}{l}\text { Industrial } \\
\quad \text { Area } 74 \text { (South Sacramento) }\end{array}$} \\
\hline & $\begin{array}{l}\text { Leasable } \\
(\mathrm{Sq}, \mathrm{Ft} \text {.) }\end{array}$ & $\begin{array}{l}\text { Vacant } \\
(\text { Sq.Ft. })\end{array}$ & Vacancy Rate & $\begin{array}{l}\text { Absorption } \\
\text { (Sq,Ft.) }\end{array}$ & $\begin{array}{l}\text { Lease Rates } \\
\left(\mathbf{S q}, \mathrm{Ft}_{1}\right)\end{array}$ \\
\hline Third Quarter 2004 & $4,989,758$ & 24,404 & $0.50 \%$ & 9,890 & $\begin{array}{l}.32 / 5 / \text { Mo for Whse } \\
.62 / 5 f / M o \text { for R\&D }\end{array}$ \\
\hline First Quarter 2009 & $5,116,607$ & 179,602 & $3.50 \%$ & 15,375 & $\begin{array}{l}0.37 / \mathrm{Sf} / \text { Mo for Whse } \\
0.84 / \mathrm{Sf} / \mathrm{Mo} \text { for R\&D }\end{array}$ \\
\hline Percent Change & $2.54 \%$ & $635.95 \%$ & $3.00 \%$ & $55.46 \%$ & $\begin{array}{l}15.46 \% \text { for Whse } \\
35.48 \% \text { for R\&D }\end{array}$ \\
\hline
\end{tabular}

Figure 6.12 